Renar kabl e I nf I uence of St ruct ur es ar ound

Rheni um (V) Center s Const ruct ed in

Pol yoxot ungst at es for Met hanol Dehydr ogenat i on under Vi si bl e Li ght I rradi at i on

\begin{tabular}{|c|c|}
\hline 著者 & $\begin{array}{l}\text { Kat o Chi ka Nozaki, Nakayama Ryut a, Hat t or i } \\
\text { Shot a, Amano H dekuni, Naki no Yuki }\end{array}$ \\
\hline $\begin{array}{l}\text { jour nal or } \\
\text { publ i cati on title }\end{array}$ & $\begin{array}{l}\text { British Journal of Appl i ed Sci ence and } \\
\text { Technol ogy }\end{array}$ \\
\hline vol une & 4 \\
\hline nunber & 16 \\
\hline page range & $2302-2319$ \\
\hline year & $201404 \quad 10$ \\
\hline 出版者 & SCI ENCEDOMAI N I nt er nat i onal \\
\hline 権利 & 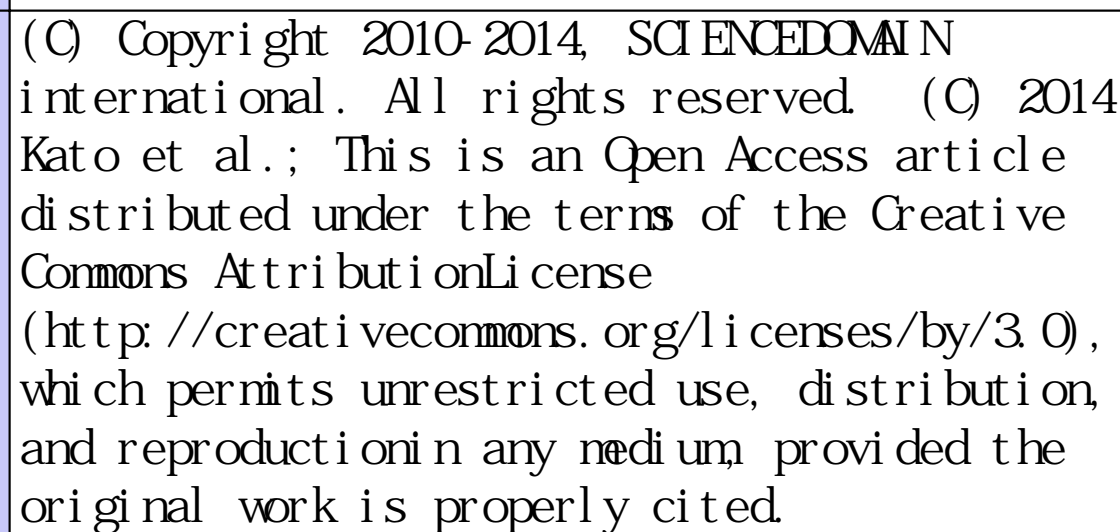 \\
\hline URL & ht t p: //hdl . handl e. net /10297/7778 \\
\hline
\end{tabular}




\title{
Remarkable Influence of Structures around Rhenium(V) Centers Constructed in Polyoxotungstates for Methanol Dehydrogenation under Visible Light Irradiation
}

\author{
Chika Nozaki Kato ${ }^{1,2^{*}}$, Ryuta Nakayama ${ }^{1}$, Shota Hattori ${ }^{1}$, \\ Hidekuni Amano ${ }^{1}$ and Yuki Makino ${ }^{1}$ \\ ${ }^{1}$ Department of Chemistry, Faculty of Science, Shizuoka University, 836 Ohya, Suruga-ku, \\ Shizuoka 422-8529, Japan \\ ${ }^{2}$ Green Chemistry Research Division, Research Institute of Green Science and Technology, \\ Shizuoka University, Ohya, Suruga-ku, Shizuoka 422-8529, Japan
}

\section{ABSTRACT}

The synthesis and characterization of $\alpha_{1}$-Dawson-type mono-rhenium(V)-substituted polyoxotungstate, $\left[\alpha_{1}-\mathrm{P}_{2} \mathrm{~W}_{17} \mathrm{Re}^{\vee} \mathrm{O}_{62}\right]^{7-}(\mathbf{1})$, are described. The dimethylammonium salt of $\mathbf{1}$, $\left[\mathrm{Me}_{2} \mathrm{NH}_{2}\right]_{7}\left[\alpha_{1}-\mathrm{P}_{2} \mathrm{~W}_{17} \mathrm{Re}^{\mathrm{V}} \mathrm{O}_{62}\right] \cdot 9 \mathrm{H}_{2} \mathrm{O} \quad\left(\mathrm{Me}_{2} \mathrm{NH}_{2}-1\right)$, was obtained as analytically pure homogeneous black-blue crystals by reacting mono-lacunary $\alpha_{1}$-Dawson polyoxotungstate with $\left[\mathrm{Re}^{\mathrm{IV}} \mathrm{Cl}_{6}\right]^{2-}$ in $\mathrm{CH}_{3} \mathrm{COOH} / \mathrm{CH}_{3} \mathrm{COOLi}$ buffer, followed by crystallization via a vapor diffusion from acetonitrile/ethanol. Characterization was also accomplished by X-ray crystallography, elemental analysis, TG/DTA, FTIR, UV-vis, and solution ${ }^{31} \mathrm{P}$ NMR spectroscopy; these results showed that the polyoxoanion 1 was a monomeric $\alpha$-Dawson structure, in which the rhenium $(\mathrm{V})$ ion was coordinated to the monovacant site of $\left[\alpha_{1}\right.$ $\left.\mathrm{LiP}_{2} \mathrm{~W}_{17} \mathrm{O}_{61}\right]^{9-}$, resulting in an overall $C_{1}$ symmetry. The polyoxoanion $1,\left[\mathrm{O}\left\{\operatorname{Re}^{\vee}(\mathrm{OH})\left(\alpha_{2}-\right.\right.\right.$ $\left.\left.\left.\mathrm{P}_{2} \mathrm{~W}_{17} \mathrm{O}_{61}\right)\right\}_{2}\right]^{14-}(2)$, and $\left[\alpha-\mathrm{PW}_{11} \mathrm{Re}^{\mathrm{V}} \mathrm{O}_{40}\right]^{4-}(3)$ showed the hydrogen evolution from methanol under visible light irradiation $(\geq 400 \mathrm{~nm})$ in the presence of titanium dioxide. The activities were remarkably depended on the rhenium $(\mathrm{V})$ sites in $\mathbf{1}-\mathbf{3}$; polyoxoanion $\mathbf{2}$ possessing the dirhenium(V)-oxido-bridged site showed the highest activities among these complexes.

Keywords: Rhenium(V); polyoxometalate; crystal structure; photocatalyst; methanol dehydrogenation

\section{INTRODUCTION}

Since the Honda-Fujishima effect, i.e., photoinduced water splitting by titanium dioxide $\left(\mathrm{TiO}_{2}\right)$ and platinum electrodes was first reported, various photocatalytic materials have been investigated, because the generated hydrogen $\left(\mathrm{H}_{2}\right)$ is a clean and renewable fuel source [16]. Although $\mathrm{TiO}_{2}$ is one of the most promising photocatalysts owing to its sufficient photostability, commercial availability, easy preparation, and its high activity for a wide range of photocatalytic reactions, it absorbs only ultraviolet (UV) light because of its wide band gap (varying from 3.0 to $3.2 \mathrm{eV}$, depending on the crystal structure); this limits the use of sunlight as an irradiation source in photocatalytic reactions $[7,8]$. One of the most powerful

* Tel.: +8154 238 4764; fax: +81542373384.

E-mail address: sckatou@ipc.shizuoka.ac.jp. 
approaches to developing visible-light-driven $\mathrm{TiO}_{2}$ materials is surface modification. To date, numerous $\mathrm{TiO}_{2}$ materials have been prepared by sensitizing transition metals [8-16], organic dyes [4, 7, 17-22], and organic moieties [23-29], and they show high activities in the presence of cocatalysts for various photoreactions. Although these are excellent studies, there is still room for improving $\mathrm{TiO}_{2}$-based photocatalytic systems by including a sensitizer and a cocatalyst.

Polyoxometalates have attracted considerable attention because of their high versatility and unique range of properties; these include catalytic and biological activities and/or photochemical, electrochromic, and magnetic properties [30-32]. Photocatalytic systems constructed using $\mathrm{TiO}_{2}$ and polyoxometalates, e.g., $\mathrm{PW}_{12} \mathrm{O}_{40}{ }^{3-}, \mathrm{PMO}_{12} \mathrm{O}_{40}{ }^{3-}, \mathrm{GeW}_{12} \mathrm{O}_{40}{ }^{4-}$, $\mathrm{SiW}_{12} \mathrm{O}_{40}{ }^{4-}, \mathrm{BW}_{12} \mathrm{O}_{40}{ }^{5-}, \alpha-\mathrm{P}_{2} \mathrm{~W}_{18} \mathrm{O}_{62}{ }^{6-}$, and $\alpha_{2}-\mathrm{P}_{2} \mathrm{~W}_{17} \mathrm{O}_{61}{ }^{10-}$, also exhibit efficient photocatalytic activities under visible light irradiation; however, they required a pretreatment by UV irradiation to form "heteropoly bule" species, and large amounts of cocatalyst [33-38]. Recently, we demonstrated the catalytic activities of $\alpha_{2}$-Dawson and Keggin rhenium(V)coordinated polyoxotungstates, $\left[\mathrm{O}\left\{\mathrm{Re}^{\mathrm{V}}(\mathrm{OH})\left(\alpha_{2}-\mathrm{P}_{2} \mathrm{~W}_{17} \mathrm{O}_{61}\right)\right\}_{2}\right]^{14-}$ and $\left[\alpha-\mathrm{PW}_{11} \mathrm{Re}^{\mathrm{V}} \mathrm{O}_{40}\right]^{4-}$, in $\mathrm{H}_{2}$ evolution from water vapor and an aqueous solution of EDTA.2Na (ethylenediamine tetraacetic acid disodium salt) in the presence of $\mathrm{TiO}_{2}$ under visible light irradiation $(\geq 400$ and $\geq 420 \mathrm{~nm}$ ) [39, 40]. In this system, the pretreatment by UV irradiation was not necessary, and the rhenium compounds exhibited high photocatalytic activities without cocatalyst. Thus, the rhenium(V)-coordinated polyoxometalates were useful compounds for development of visible-light-driven $\mathrm{TiO}_{2}$-based photocatalyst; however, the structure dependence of rhenium(V) sites constructed in polyoxometalate is still open to discussion because significant $\left[\alpha-\mathrm{PW}_{11} \mathrm{Re}^{\vee} \mathrm{O}_{40}\right]^{4-}$ decomposition was observed in an EDTA.2Na aqueous solution during light irradiation.

In this study, we first synthesized $\alpha_{1}$-Dawson-type mono-rhenium( $\mathrm{V}$ )-substituted polyoxotungstate $\left[\mathrm{Me}_{2} \mathrm{NH}_{2}\right] 7\left[\alpha_{1}-\mathrm{P}_{2} \mathrm{~W}_{17} \mathrm{Re}^{\mathrm{V}} \mathrm{O}_{62}\right] \cdot 9 \mathrm{H}_{2} \mathrm{O}\left(\mathrm{Me}_{2} \mathrm{NH}_{2}-1\right)$ and characterized it using $\mathrm{X}$-ray crystallography, elemental analysis, thermogravimetric analysis/differential thermal analysis (TG/DTA), and Fourier-transform infrared (FTIR), UV-visible, and solution ${ }^{31} \mathrm{P}$ nuclear magnetic resonance (NMR) spectroscopies. To investigate the structure dependence of rhenium $(\mathrm{V})$ sites for the photocatalytic reactions, we focused on the methanol dehydrogenation catalyzed by $\mathbf{M e}_{2} \mathbf{N H}_{2}-\mathbf{1}, \mathrm{K}_{14}\left[\mathrm{O}\left\{\mathrm{Re}^{\vee}(\mathrm{OH})\left(\alpha_{2}-\mathrm{P}_{2} \mathrm{~W}_{17} \mathrm{O}_{61}\right)\right\}_{2}\right] \cdot 21 \mathrm{H}_{2} \mathrm{O}$ $(\mathrm{K}-2)$, and $\left[\mathrm{Me}_{2} \mathrm{NH}_{2}\right]_{4}\left[\alpha-\mathrm{PW}_{11} \mathrm{Re}^{\mathrm{V}} \mathrm{O}_{40}\right]\left(\mathrm{Me}_{2} \mathrm{NH}_{2}-3\right)$ under visible light irradiation $(\geq 400 \mathrm{~nm})$ in the presence of $\mathrm{TiO}_{2}$. Here, we report full details of the synthesis and molecular structure of complex 1, and demonstrate the photocatalytic activities and stabilities of complexes $1-\mathbf{3}$.

\section{EXPERIMENTAL DETAILS}

\subsection{Materials}

$\mathrm{K}_{14}\left[\mathrm{O}\left\{\mathrm{Re}^{\vee}(\mathrm{OH})\left(\alpha_{2}-\mathrm{P}_{2} \mathrm{~W}_{17} \mathrm{O}_{61}\right)\right\}_{2}\right] \cdot 21 \mathrm{H}_{2} \mathrm{O} \quad(\mathrm{K}-2) \quad[40], \quad\left[\mathrm{Me}_{2} \mathrm{NH}_{2}\right]_{4}\left[\alpha-\mathrm{PW}_{11} \mathrm{Re}^{\vee} \mathrm{O}_{40}\right] \quad\left(\mathrm{Me}_{2} \mathbf{N H}_{2}-3\right)$ [40], $\mathrm{K}_{9}\left[\alpha_{1}-\mathrm{LiP}_{2} \mathrm{~W}_{17} \mathrm{O}_{61}\right] \cdot 22 \mathrm{H}_{2} \mathrm{O}$ [41], and $\mathrm{K}_{10}\left[\alpha_{2}-\mathrm{P}_{2} \mathrm{~W}_{17} \mathrm{O}_{61}\right] \cdot 27 \mathrm{H}_{2} \mathrm{O}$ [42] were synthesized as described in the literatures. The number of solvated water molecules was determined by TG/DTA analyses. $\mathrm{K}_{2}\left[\mathrm{Re}^{\mathrm{IV}} \mathrm{Cl}_{6}\right]$ was purified by the reprecipitation from water/ethanol. $\mathrm{TiO}_{2}$ (anatase/rutile $=80 / 20 ; 99.9 \%$; $-5 \mu \mathrm{m}$ ) was obtained from Wako Pure Chemical Industries, Ltd. Other reagents and solvents were obtained and used as received from commercial sources.

\subsection{Instrumentation/analytical procedures}


87 The elemental analysis was carried out by using a Mikroanalytisches Labor Pascher instrument (Remagen, Germany). The samples were dried overnight at room temperature under $10^{-3}-10^{-4}$ Torr vacuum before analysis. The infrared spectra were recorded on a Parkin Elmer Spectrum100 FT-IR spectrometer in $\mathrm{KBr}$ disks at room temperature. Thermogravimetric (TG) and differential thermal analyses (DTA) data were obtained using a Rigaku Thermo Plus 2 series TG/DTA TG 8120. The TG/DTA measurements were performed in air with a temperature increase of $4{ }^{\circ} \mathrm{C}$ per min between 20 and $500{ }^{\circ} \mathrm{C}$. The ${ }^{31} \mathrm{P}-\left\{{ }^{1} \mathrm{H}\right\} \quad(242.95 \mathrm{MHz})$ nuclear magnetic resonance (NMR) spectra in solutions were recorded in 5-mm outer diameter tubes on a JEOL ECA-600 NMR spectrometer (Shizuoka University). The ${ }^{31} \mathrm{P}$ NMR spectra were measured in $\mathrm{CH}_{3} \mathrm{COOLi}-\mathrm{D}_{2} \mathrm{O}$ and $\mathrm{D}_{2} \mathrm{O}$ with reference to an external standard of $85 \% \mathrm{H}_{3} \mathrm{PO}_{4}$ in a sealed capillary. Chemical shifts were reported as negative on the $\delta$ scale for resonance upfield of $\mathrm{H}_{3} \mathrm{PO}_{4}(\delta 0)$. Solution UV-vis spectra were recorded on a Perkin-Elmer Spectrum Lambda 650 spectrophotometer. The positions of sharp bands were automatically determined by software of UV-visible spectrometer, and those of broad bands were picked up at the highest values in the ASCII files. Potentiometric titration was carried out with $0.841 \mathrm{mmol} / \mathrm{L}$ tetra- $n$-butylammonium hydroxide as a titrant under argon atmosphere [43]. The compound $\mathbf{M e}_{2} \mathbf{N H}_{2}-1(4.12 \mu \mathrm{mol})$ was dissolved in acetonitrile $(20 \mathrm{~mL})$ at $25{ }^{\circ} \mathrm{C}$, and the solution was stirred for approximately $5 \mathrm{~min}$. The titration data were obtained with a pH meter (Mettler Toledo). Data points were obtained in milivolt. A solution of tetra- $n$-butylammonium hydroxide $(0.841 \mathrm{mmol} / \mathrm{L})$ was syringed into the suspension in 0.20-equivalent intervals.

\subsection{Synthesis of $\left[\mathrm{Me}_{2} \mathrm{NH}_{2}\right]_{7}\left[\alpha_{1}-\mathrm{P}_{2} \mathrm{~W}_{17} \mathrm{Re}^{\mathrm{V}} \mathrm{O}_{62}\right] \cdot 9 \mathrm{H}_{2} \mathrm{O}\left(\mathrm{Me}_{2} \mathrm{NH}_{2}-1\right)$}

A solution of $\mathrm{K}_{2}\left[\mathrm{Re}^{\mathrm{IV}} \mathrm{Cl}_{6}\right](0.365 \mathrm{~g} ; 0.765 \mathrm{mmol})$ dissolved in $10 \mathrm{~mL}$ of water was added to a solution of $\mathrm{K}_{9}\left[\alpha_{1}-\mathrm{LiP}_{2} \mathrm{~W}_{17} \mathrm{O}_{61}\right] \cdot 22 \mathrm{H}_{2} \mathrm{O}(1.865 \mathrm{~g} ; 0.379 \mathrm{mmol})$ dissolved in $25 \mathrm{~mL}$ of $\mathrm{CH}_{3} \mathrm{COOH} / \mathrm{CH}_{3} \mathrm{COOLi}$ buffer solution $(\mathrm{pH}=4.5)$ at $25^{\circ} \mathrm{C}$. After stirring for $4 \mathrm{~h}$ at $25^{\circ} \mathrm{C}$ in the dark, a solid $\left[\mathrm{Me}_{2} \mathrm{NH}_{2}\right] \mathrm{Cl}(3.114 \mathrm{~g} ; 38.3 \mathrm{mmol})$ was added to the solution, followed by stirring overnight at $25^{\circ} \mathrm{C}$. A deep blue-colored precipitate was collected using a membrane filter (JG $0.2 \mu \mathrm{m}$ ). At this stage, a crude product was obtained in $1.74 \mathrm{~g}$ yield. For crystallization, the crude product $(1.74 \mathrm{~g})$ was dissolved in $350 \mathrm{~mL}$ of acetonitrile at $25{ }^{\circ} \mathrm{C}$; the resulting solution was filtered through a folded filter paper (Whatman \#5). Black block crystals were obtained via vapor diffusion from methanol at $25{ }^{\circ} \mathrm{C}$. The yield was $0.464 \mathrm{~g}$. The percent yield was calculated on the basis of [mol of $\left.\mathbf{M e}_{2} \mathrm{NH}_{2}-1\right] /\left[\mathrm{mol}\right.$ of $\left.\mathrm{K}_{9} \mathrm{Li}\left[\alpha_{1}-\mathrm{P}_{2} \mathrm{~W}_{17} \mathrm{O}_{61}\right] \cdot 22 \mathrm{H}_{2} \mathrm{O}\right] \times$ 100 and was $25 \%$. Elemental analysis results showed $\mathrm{C}, 3.57 ; \mathrm{H}, 1.42 ; \mathrm{N}, 2.05 ; \mathrm{P}, 1.28 ; \mathrm{Re}$, 4.00; W, 66.0; K, 0.03; Li, <0.01\%. Calculations for $\left[\left(\mathrm{CH}_{3}\right)_{2} \mathrm{NH}_{2}\right]_{7}\left[\alpha_{1}-\mathrm{P}_{2} \mathrm{~W}_{17} \mathrm{ReO}_{62}\right] \cdot \mathrm{xH}_{2} \mathrm{O}(\mathrm{x}=$ 2) $=\mathrm{H}_{60} \mathrm{C}_{14} \mathrm{~N}_{7} \mathrm{O}_{64} \mathrm{P}_{2} \mathrm{ReW}_{17}$ : C, 3.56; $\mathrm{H}, 1.28 ; \mathrm{N}, 2.08 ; \mathrm{P}, 1.31 ; \mathrm{Re}, 3.94 ; \mathrm{W}, 66.2 \%$. A weight loss of $2.54 \%$ was observed during overnight drying at room temperature under $10^{-3}-10^{-4}$ torr before analysis, suggesting seven water molecules (2.60\%). TG/DTA under atmospheric conditions showed a weight loss of $12.2 \%$ below $500{ }^{\circ} \mathrm{C}$ with an exothermic point at 381.1 ${ }^{\circ} \mathrm{C}$. A clear endothermic point was not observed; calculations showed $10.0 \%$ for the sum of seven dimethylammonium ions and nine water molecules. IR ( $\mathrm{KBr}$ disk) results in the 1300 $-400 \mathrm{~cm}^{-1}$ region (polyoxometalate region) showed: $1094 \mathrm{~m}, 1077 \mathrm{~m}, 1014 \mathrm{w}, 959 \mathrm{~s}, 918 \mathrm{~m}$,

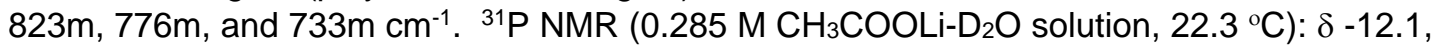
-12.4. UV-visible absorption (in $\mathrm{H}_{2} \mathrm{O}, 1.0 \times 10^{-5}$ and $1.0 \times 10^{-4} \mathrm{M}$ ) showed: $\lambda 263 \mathrm{~nm}(\varepsilon 4.4 \times$ $\left.10^{4} \mathrm{M}^{-1} \mathrm{~cm}^{-1}\right), \lambda 310 \mathrm{~nm}\left(\varepsilon 1.8 \times 10^{4} \mathrm{M}^{-1} \mathrm{~cm}^{-1}\right)$, and $\lambda 468 \mathrm{~nm}\left(\varepsilon 3.7 \times 10^{3} \mathrm{M}^{-1} \mathrm{~cm}^{-1}\right)$.

\subsection{X-ray crystallography}

A black block crystal of $\mathbf{M e}_{2} \mathrm{NH}_{2}-1\left(0.180 \times 0.050 \times 0.040 \mathrm{~mm}^{3}\right)$ was mounted in a loop. Data were collected by a Rigaku Marcury70 diffractometer using monochromated Mo K $\alpha$ radiation $(\lambda=0.71070 \AA)$ at $113 \mathrm{~K}$. Data were collected and processed using CrystalClear 
software for Windows. The structural analysis was performed using the CrystalStructure software for Windows. All structures were solved by SHELXS-97 (direct methods) and refined by SHELXL-97 [44]. Since one rhenium atom was disordering over twelve tungsten sites (W(4) - W (15)) in polyoxoanion 1, the occupancies for the rhenium and tungsten sites were fixed at $1 / 12$ and $11 / 12$ throughout the refinement. The seven dimethylammonium ions and some acetonitrile and ethanol molecules were observed; however, no acetonitrile and ethanol solvent molecules were observed by elemental analysis and ${ }^{1} \mathrm{H}$ NMR spectroscopy. Thus, the solvent molecules evaporate gradually when crystals are removed from acetonitrile solution. Accordingly, the residual electron density was removed using the SQUEEZE routine in PLATON [45].

\subsection{X-ray crystallography}

$\mathrm{C}_{14} \mathrm{H}_{60} \mathrm{~N}_{7} \mathrm{O}_{64} \mathrm{P}_{2} \mathrm{ReW}_{17} ; \mathrm{M}=4724.24$, triclinic, space group $P-1$ (\#2), $a=13.317(5) \AA, b=$ 13.377(4) $\AA, c=24.248(9) \AA, \alpha=79.24(2)^{\circ}, \beta=79.78(2)^{\circ}, \gamma=68.28(2)^{\circ}, V=3914(3) \AA^{3}, Z=$ 2, $D_{\mathrm{c}}=4.008 \mathrm{~g} / \mathrm{cm}^{3}, \mu(\mathrm{Mo}-\mathrm{K} \alpha) 265.749 \mathrm{~cm}^{-1} . R_{1}=0.0678(I>2 \sigma(I)), w R_{2}=0.1837$ (for all data). GOF $=1.079$ (26430 total reflections, 14529 unique reflections where $I>2 \sigma(I)$ ). CCDC reference number 968914 contains the supplementary crystallographic data for this paper. These data can be obtained free of charge at www.ccdc.cam.ac.uk/conts/retrieving.html [or from Cambridge Crystallographic Data Centre, 12 Union Road, Cambridge CB2 1EZ, UK; Fax: +44-1223-336-033; E-mail: deposite@ccdc.cam.ac.uk.]

\subsection{Catalytic reaction experiments}

For methanol dehydrogenation, $\mathrm{TiO}_{2}$ (anatase/rutile $\left.=80 / 20\right)(200 \mathrm{mg}$ ) and rhenium compounds were suspended in $10 \mathrm{~mL}$ of methanol. The mixture was placed into a glass reaction vessel; this was connected to a Pyrex conventional closed gas circulation system $\left(245.5 \mathrm{~cm}^{3}\right)$. The compounds $\mathbf{M e}_{2} \mathrm{NH}_{2}-1$ (2.8 - $9.4 \mathrm{mg} ; 0.6-1.9 \mu \mathrm{mol}$ of $\left.\mathrm{Re}\right), \mathbf{K}-2$ (2.4 - 10 $\mathrm{mg} ; 0.6-2.0 \mu \mathrm{mol}$ of $\mathrm{Re}$ ), and $\mathrm{Me}_{2} \mathrm{NH}_{2}-3$ (1.8 - 6.1 mg; $0.6-2.0 \mu \mathrm{mol}$ of $\mathrm{Re}$ ) were used for the photoreactions. The photoreaction was started by light irradiation with a $300 \mathrm{~W}$ Xe lamp equipped with a cut-off filter $(\lambda \geq 400 \mathrm{~nm}) . \mathrm{H}_{2}, \mathrm{O}_{2}, \mathrm{CO}$, and $\mathrm{CH}_{4}$ were analyzed by $\mathrm{GC}$ (TCD, Molecular Sieve $5 \mathrm{~A}$ stainless columns): the samples were assigned after they were compared with authentic samples analyzed under the same conditions. Turnover number (TON) was calculated as 2[hydrogen evolved (mol)]/[Re atoms (mol)]. Formaldehyde was observed by the published method [46].

\section{RESULTS AND DISCUSSION}

\subsection{Synthesis and molecular structure of $\left[\mathrm{Me}_{2} \mathrm{NH}_{2}\right] 7\left[\alpha_{1}-\mathrm{P}_{2} \mathrm{~W}_{17} \mathrm{Re}^{\mathrm{V}} \mathrm{O}_{62}\right] \cdot 9 \mathrm{H}_{2} \mathrm{O}\left(\mathrm{Me}_{2} \mathrm{NH}_{2}-1\right)$}

The dimethylammonium salt of $\mathbf{1}$, $\left[\mathrm{Me}_{2} \mathrm{NH}_{2}\right]_{7}\left[\alpha_{1}-\mathrm{P}_{2} \mathrm{~W}_{17} \mathrm{Re}^{\mathrm{V}} \mathrm{O}_{62}\right] \cdot 9 \mathrm{H}_{2} \mathrm{O} \quad\left(\mathbf{M e}_{2} \mathbf{N H}_{2}-\mathbf{1}\right)$, was synthesized by the direct reaction of 2 equiv of $\mathrm{K}_{2} \mathrm{Re}^{\mathrm{IV}} \mathrm{Cl}_{6}$ with mono-lacunary $\alpha_{1}$-Dawson polyoxotungstate, $\left[\alpha_{1}-\mathrm{LiP}_{2} \mathrm{~W}_{17} \mathrm{O}_{61}\right]^{9-}$, in a $\mathrm{CH}_{3} \mathrm{COOH} / \mathrm{CH}_{3} \mathrm{COOLi}$ aqueous buffer solution $(\mathrm{pH}$ $=4.5$ ) under air, at $25^{\circ} \mathrm{C}$; this was followed by addition of excess $\mathrm{Me}_{2} \mathrm{NH}_{2} \mathrm{Cl}$, forming a dark blue precipitate. The formation of polyoxoanion 1 is represented by the ionic balance shown in Eq. 1, in which rhenium(IV) is oxidized to rhenium(V), as observed for compounds K-2 and $\mathbf{M e}_{2} \mathbf{N H}_{2}-3$ [39,40]. Notably, polyoxoanion 1 was gradually isomerized to the $\alpha_{2}$-isomer during the reaction of $\mathrm{K}_{2} \mathrm{Re}^{\mathrm{IV}} \mathrm{Cl}_{6}$ with $\left[\alpha_{1}-\mathrm{LiP}_{2} \mathrm{~W}_{17} \mathrm{O}_{61}\right]^{9-}$ in aqueous solution; the $\mathrm{CH}_{3} \mathrm{COOH} / \mathrm{CH}_{3} \mathrm{COOLi}$ aqueous buffer solution is therefore indispensable in inhibiting isomerization, as observed for $\left[\alpha_{1}-\mathrm{LiP}_{2} \mathrm{~W}_{17} \mathrm{O}_{61}\right]^{9-}[41]$. In addition, the reaction temperature 
should be kept at ca. $25^{\circ} \mathrm{C}$, even in a buffer solution, because heat treatment accelerated the isomerization. An excess of $\mathrm{K}_{2} \mathrm{Re}^{\mathrm{IV}} \mathrm{Cl}_{6}$ was therefore required to complete (accelerate) the coordination of rhenium ion to the mono-vacant site of $\left[\alpha_{1}-\mathrm{LiP}_{2} \mathrm{~W}_{17} \mathrm{O}_{61}\right]^{9-}$. For purification, the unreacted $\mathrm{K}_{2} \mathrm{Re}^{\mathrm{IV}} \mathrm{Cl}_{6}$ was completely removed by crystallization via vapor diffusion from acetonitrile/ethanol.

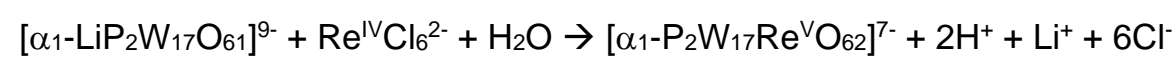

The sample was dried overnight at room temperature under a vacuum of $10^{-3}-10^{-4}$ Torr for elemental analysis. The elemental results for $\mathrm{C}, \mathrm{H}, \mathrm{N}, \mathrm{Re}, \mathrm{P}$, and $\mathrm{W}$ were in good agreement with the calculated values for the chemical formula of $\mathbf{M e}_{2} \mathrm{NH}_{2}-1$ with two hydrated water molecules. The presence of seven dimethylammonium ions suggested that the oxidation state of the rhenium site was 5+; this was also supported by the fact that no protonation was observed in potentiometric titration with tetra- $n$-butylammonium hydroxide in acetonitrile. The weight loss observed during drying before analysis was $2.54 \%$ for $\mathbf{M e}_{2} \mathbf{N H}_{2}-\mathbf{1}$, corresponding to seven weakly solvated or adsorbed water molecules. However, during TG/DTA under atmospheric conditions, a weight loss of $12.2 \%$ was observed below $500{ }^{\circ} \mathrm{C}$, corresponding to seven dimethylammonium ions and nine water molecules.

The $X$-ray structural analysis of crystalline $\left[\mathrm{Me}_{2} \mathrm{NH}_{2}\right]_{7}\left[\alpha_{1}-\mathrm{P}_{2} \mathrm{~W}_{17} \mathrm{Re}^{\vee} \mathrm{O}_{62}\right] \cdot 2 \mathrm{H}_{2} \mathrm{O}$ revealed that the molecular structure of $\mathbf{1}$ was identical to that of a monomeric $\alpha$-Dawson polyoxotungstate, $\left[\alpha-\mathrm{P}_{2} \mathrm{~W}_{18} \mathrm{O}_{62}\right]^{6-}$, as shown in Figure 1. The bond lengths and bond angles are shown in Appendix. As a result of the high-symmetry space group, 12 tungsten sites $[\mathrm{W}(4)-\mathrm{W}(15)]$ were disordered and a mono-rhenium-substituted site was not identified, as observed for $\left[\mathrm{W}_{9} \mathrm{ReO}_{32}\right]^{5-}[47]$ and $\left[\alpha-\mathrm{PW}_{11} \mathrm{Re}^{\mathrm{V}} \mathrm{O}_{40}\right]^{5-}[48]$. Some ethanol and acetonitrile molecules were observed in a single crystal of $\mathbf{M e}_{2} \mathbf{N H}_{2}-\mathbf{1}$; however, no acetonitrile and ethanol solvent molecules were observed by elemental analysis and ${ }^{1} \mathrm{H}$ NMR spectroscopy. The solvent molecules therefore evaporate gradually when the crystals are removed from acetonitrile solution.

The FTIR spectrum of compound $\mathbf{M e}_{2} \mathbf{N H}_{2}-\mathbf{1}$, which was obtained using a $\mathrm{KBr}$ disk, is shown in Figure 2. The positions of all the bands $(1094,1077,1014,959,918,823,776$, and 733 $\mathrm{cm}^{-1}$ ) in the polyoxoanion region of this compound are characteristic of polyoxoanions; however, they were different from those for $\left[\alpha_{1}-\mathrm{LiP}_{2} \mathrm{~W}_{17} \mathrm{O}_{61}\right]^{9-}(1122,1092,1011,944,908$, 828,783 , and $\left.744 \mathrm{~cm}^{-1}\right), \mathrm{K}-2\left(1091,1018,955,910\right.$, and $\left.788 \mathrm{~cm}^{-1}\right)$, and $\left[\alpha-\mathrm{P}_{2} \mathrm{~W}_{18} \mathrm{O}_{62}\right]^{6-}$ $\left(1091,1020,958,912,777\right.$, and $\left.528 \mathrm{~cm}^{-1}\right)$. This suggests coordination of a rhenium(V) ion in the monovacant site of $\left[\alpha_{1}-\mathrm{LiP}_{2} \mathrm{~W}_{17} \mathrm{O}_{61}\right]^{9-}$.

The ${ }^{31} \mathrm{P}$ NMR spectrum in $\mathrm{CH}_{3} \mathrm{COOLi}-\mathrm{D}_{2} \mathrm{O}$ solution of $\mathbf{M e}_{2} \mathrm{NH}_{2}-\mathbf{1}$ showed a clear two-line spectrum, with signals at $-12.1 \mathrm{ppm}$ and $-12.4 \mathrm{ppm}$, as shown in Figure 3(a). The signals were shifted compared with those of $\left[\alpha_{1}-\mathrm{LiP}_{2} \mathrm{~W}_{17} \mathrm{O}_{61}\right]^{9-}(-8.7 \mathrm{ppm}$ and $-13.0 \mathrm{ppm})$ and $[\alpha-$ $\left.\mathrm{P}_{2} \mathrm{~W}_{18} \mathrm{O}_{62}\right]^{6-}(-12.8 \mathrm{ppm})$, indicating complete coordination of rhenium atom to monovacant site of $\left[\alpha_{1}-\mathrm{LiP}_{2} \mathrm{~W}_{17} \mathrm{O}_{61}\right]^{9-}$, as shown in Figure 1. No contamination of the sample by polyoxoanion 2 (-11.9 ppm and -12.9 ppm in $\left.\mathrm{D}_{2} \mathrm{O}\right)$ was observed; however, polyoxoanion 1 gradually isomerized to polyoxoanion 2 in aqueous solution. The ${ }^{183} \mathrm{~W}$ NMR spectrum of $\mathbf{M e}_{2} \mathrm{NH}_{2}-1$ was failed to obtain because of its low solubility in water and acetonitrile.

The UV-visible spectrum of $\mathbf{M e}_{2} \mathbf{N H}_{2}-1$ in water showed four absorption bands, at $263(\varepsilon 4.4 \times$ $\left.10^{4} \mathrm{M}^{-1} \mathrm{~cm}^{-1}\right), 310\left(\varepsilon 1.8 \times 10^{4} \mathrm{M}^{-1} \mathrm{~cm}^{-1}\right), 468\left(\varepsilon 3.7 \times 10^{3} \mathrm{M}^{-1} \mathrm{~cm}^{-1}\right)$, and $613 \mathrm{~nm}\left(\varepsilon 5.2 \times 10^{3} \mathrm{M}^{-}\right.$ $\left.{ }^{1} \mathrm{~cm}^{-1}\right)$, as shown in Figure 4. The bands at $263 \mathrm{~nm}$ and $310 \mathrm{~nm}$ were assigned to the charge transfer (CT) band of W-O bonds. The two bands at 468 and $613 \mathrm{~nm}$ were assigned to the $\mathrm{Re}^{\mathrm{V}} \rightarrow \mathrm{W}^{\mathrm{VI}}$ intervalence charge transfer (IVCT) band and the $d$ - $d$ band of the 
rhenium(V) atom, respectively $[39,40]$. It was noted that the bands at $468 \mathrm{~nm}$ and $613 \mathrm{~nm}$ for $\mathbf{M e}_{2} \mathrm{NH}_{2}-\mathbf{1}$ were significantly broader rather than those for $\mathrm{K}-2$ and $\mathbf{M e}_{2} \mathbf{N H}_{2}-\mathbf{3}$, and the positions were blue-shifted compared with those for $\mathbf{K}-\mathbf{2}(496 \mathrm{~nm}$ and $737 \mathrm{~nm})$ and $\mathbf{M e}_{2} \mathbf{N H}_{2}-$ $3(513 \mathrm{~nm}$ and $698 \mathrm{~nm})$; this also suggested coordination of the rhenium(V) ion to the

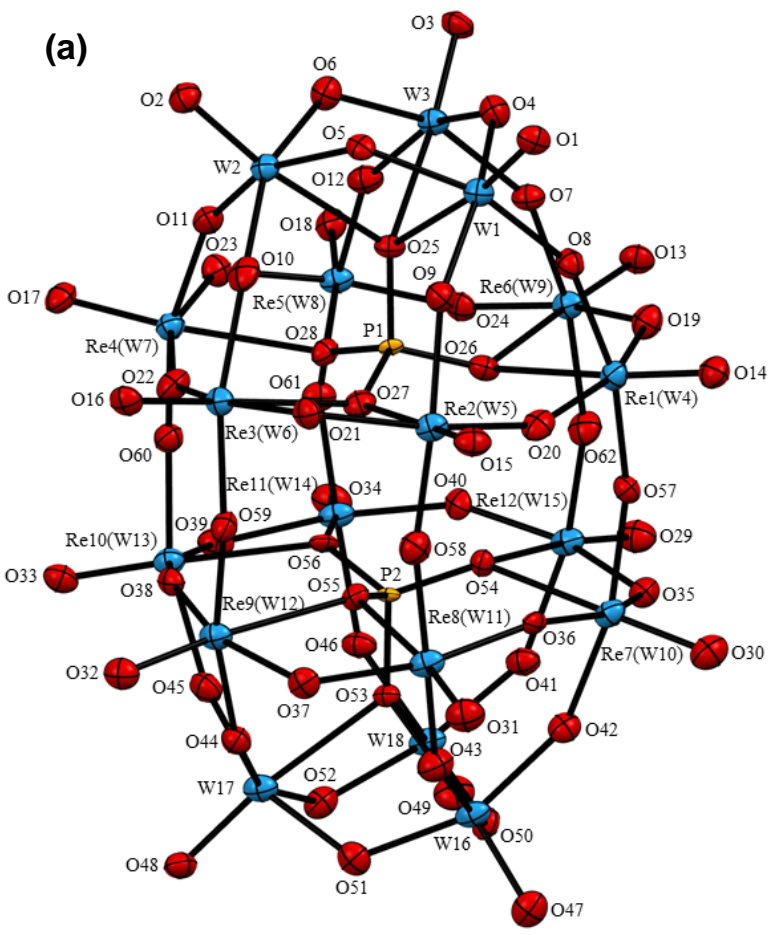

(b)

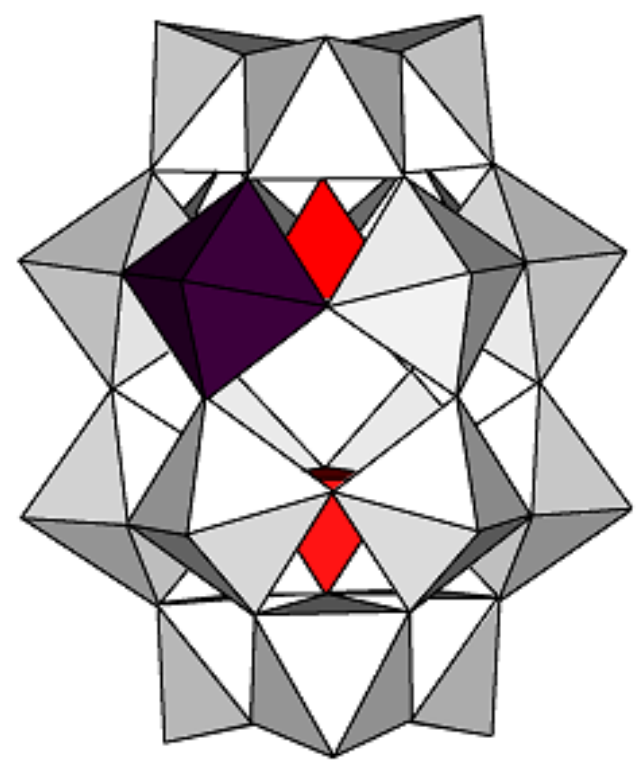

Fig. 1. (a) The molecular structure (ORTEP drawing) of polyoxoanion 1 with all atom numberings and (b) polyhedral representation of polyoxoanion 1 . In (b), $\mathrm{WO}_{6}$ and $\mathrm{ReO}_{6}$ units are represented by the white and purple octahedra, respectively. The internal $\mathrm{PO}_{4}$ units are represented by the red tetrahedra.

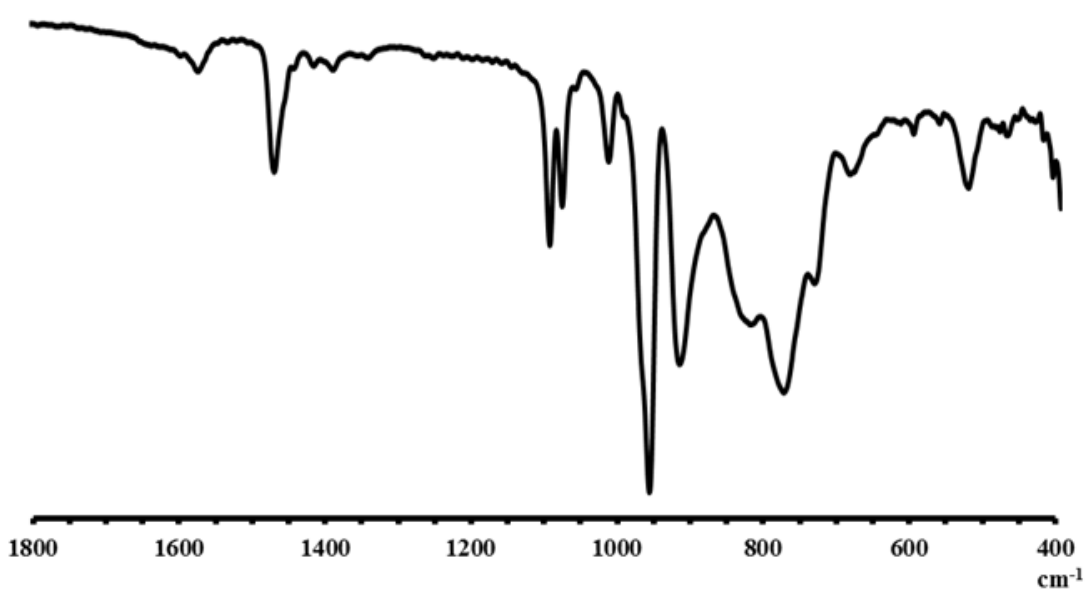

Fig. 2. FTIR spectrum as a $\mathrm{KBr}$ disk of $\mathrm{Me}_{2} \mathrm{NH}_{2}-1$. 
(a)

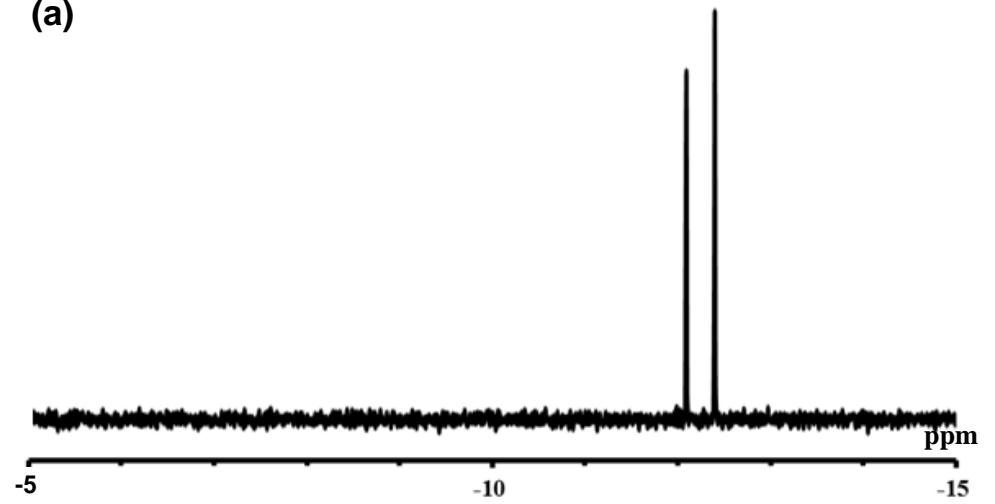

(b)

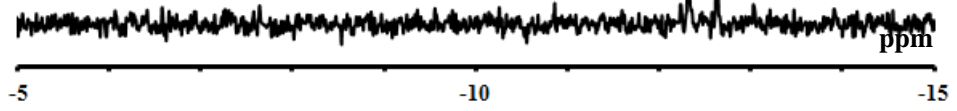

Fig. 3. ${ }^{31} \mathrm{P}$ NMR spectra in $0.285 \mathrm{M} \mathrm{CH}_{3} \mathrm{COOLi}-\mathrm{D}_{2} \mathrm{O}$ of (a) $\mathrm{Me}_{2} \mathrm{NH}_{2}-1$ and (b) after photoreaction. The spectrum was referenced to an external standard of $85 \% \mathrm{H}_{3} \mathrm{PO}_{4}$ in a sealed capillary. In (b), $\mathrm{Me}_{2} \mathrm{NH}_{2}-1(50 \mathrm{mg})$ and $\mathrm{TiO}_{2}(500 \mathrm{mg})$ were suspended in methanol $(25 \mathrm{~mL})$, and they were irradiated under the visible light $(\geq 400 \mathrm{~nm})$ for $6 \mathrm{~h}$.

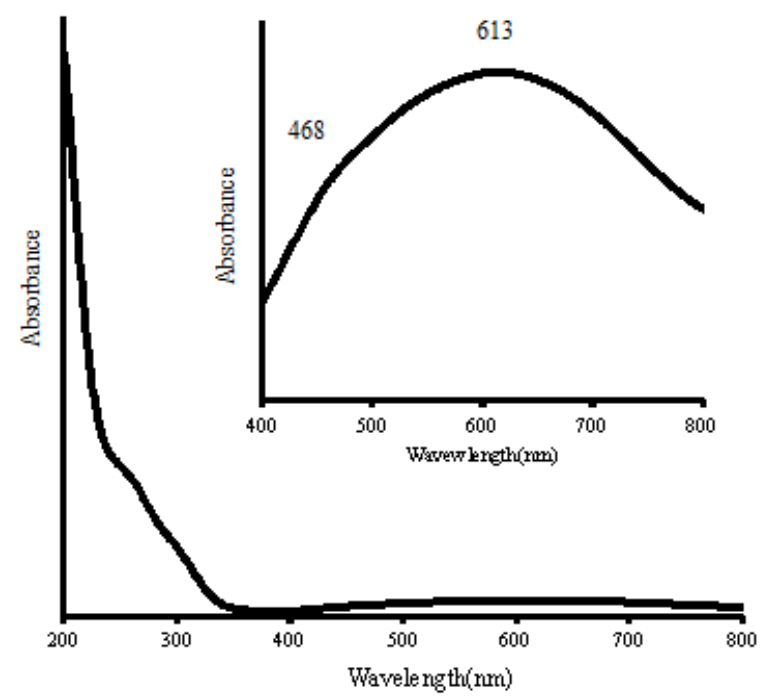

Fig. 4. UV-visible spectra in $\mathrm{H}_{2} \mathrm{O}$ of $\mathrm{Me}_{2} \mathrm{NH}_{2}-1\left(1.0 \times 10^{-5} \mathrm{M}\right)$ at $200-800 \mathrm{~nm}$. Inset: $400-800 \mathrm{~nm}\left(1.0 \times 10^{-4} \mathrm{M}\right)$. 
3.2 Catalytic activities in methanol dehydrogenation catalyzed by rhenium(V)coordinated polyoxotungstates in the presence of $\mathrm{TiO}_{2}$ under visible-light irradiation $(\geq 400 \mathrm{~nm})$

Methanol dehydrogenation catalyzed by rhenium(V)-coordinated polyoxotungstates at $25{ }^{\circ} \mathrm{C}$ in the presence of $\mathrm{TiO}_{2}$ under light irradiation $(\geq 400 \mathrm{~nm})$ was investigated; the results are summarized in Table 1. Hydrogen was evolved from methanol catalyzed by $\mathbf{M e}_{2} \mathbf{N H}_{2}-\mathbf{1}, \mathbf{K}-\mathbf{2}$, and $\mathbf{M e}_{2} \mathrm{NH}_{2}-3$. Formaldehyde was also observed; while, $\mathrm{O}_{2}, \mathrm{CO}$, and $\mathrm{CH}_{4}$ were not observed. The three rhenium $(\mathrm{V})$ compounds were hardly soluble in methanol. When a suspension of K-2 $(50 \mathrm{mg})$ and $\mathrm{TiO}_{2}(200 \mathrm{mg})$ in methanol $(25 \mathrm{~mL})$ was irradiated under visible light $(\geq 400 \mathrm{~nm})$ for $6 \mathrm{~h}$, followed by filtration through a membrane filter (JG 0,2 $\mu \mathrm{m})$, UV-vis spectrum of the filtrate showed a small band at around $220 \mathrm{~nm}$ due to a charge transfer band of $\mathrm{WVI}^{\mathrm{VI}} \mathrm{O}$; however, this was significantly smaller than that in $30 \mathrm{mM}$ EDTA.2Na aqueous solution $(25 \mathrm{~mL})$ under the same reaction conditions, as shown in Figure 5 . Even when the cesium salts of $\mathbf{1}-\mathbf{3}$ were used as catalysts, a slight leaching into methanol was observed. These results suggested that the rhenium $(\mathrm{V})$ compounds were predominantly active in the solid state under the present reaction conditions. The initial dehydrogenation rates with $\mathbf{M e}_{2} \mathbf{N H}_{2}-\mathbf{1}$ and $\mathbf{M e}_{2} \mathbf{N H}_{2}-\mathbf{3}$ were slow; while, no induction period was observed for $\mathrm{K}-2$, as shown in Figure 6 . The colors of these materials changed from white-purple to blue during the reactions; however, the blue color disappeared and the photoreactions stopped when visible light irradiation stopped.

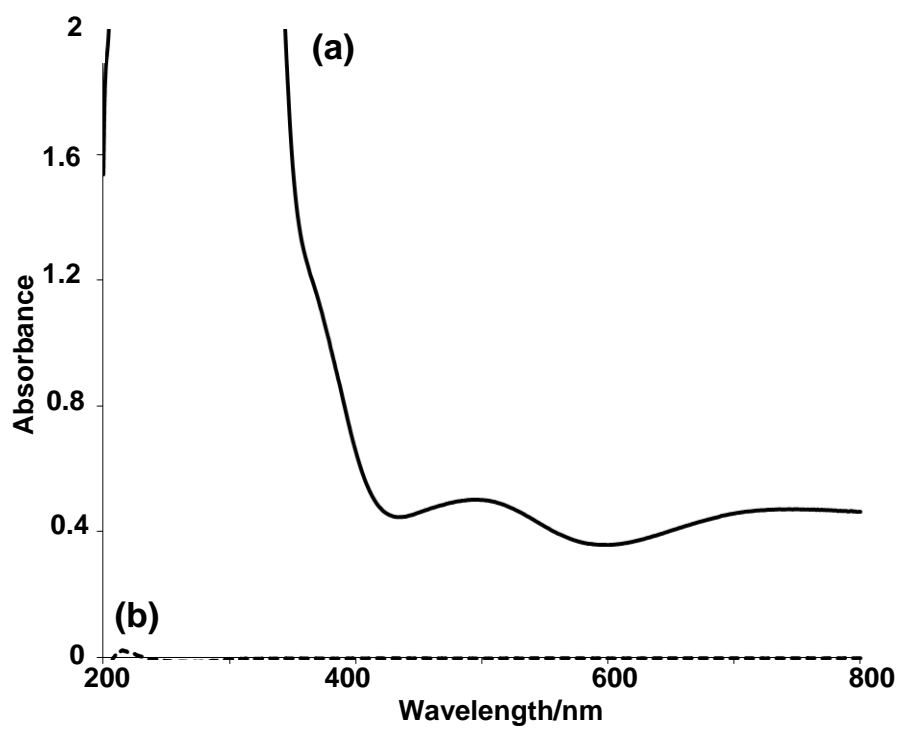

Fig. 5. UV-visible spectra of K-2 at $200-800 \mathrm{~nm}$.

$\mathrm{K}-2(50 \mathrm{mg})$ and $\mathrm{TiO}_{2}(500 \mathrm{mg}$ ) were suspended in (a) $30 \mathrm{mM}$ EDTA.2Na aqueous solution $(25 \mathrm{~mL})$ and $(\mathrm{b})$ methanol $(25 \mathrm{~mL})$, and they were irradiated under the visible light $(\geq 400 \mathrm{~nm})$ for $6 \mathrm{~h}$ at $25^{\circ} \mathrm{C}$. After a filtration through a membrane filter (JG $0.2 \mu \mathrm{m}$ ), UV-vis spectra of the filtrates were observed, respectively.

In control experiments, hydrogen was not detected when the reaction was catalyzed by $\mathrm{TiO}_{2}$. The rhenium(V)-coordinated polyoxotungstates showed no reaction in the absence of $\mathrm{TiO}_{2}$. $\mathrm{K}_{10}\left[\alpha_{2}-\mathrm{P}_{2} \mathrm{~W}_{17} \mathrm{O}_{61}\right] \cdot 27 \mathrm{H}_{2} \mathrm{O}$ also showed no reaction even in the presence of $\mathrm{TiO}_{2}$. $\mathrm{A}$ combination of rhenium(V)-coordinated sites in the polyoxotungstates and $\mathrm{TiO}_{2}$ was therefore necessary, as reported for photoreactions using an EDTA.2Na aqueous solution in 
the presence of $\mathrm{TiO}_{2}$ under light irradiation $(\geq 400 \mathrm{~nm})[39,40]$. For the three rhenium compounds ( $1.0 \mu \mathrm{mol}$ of $\mathrm{Re}$ ), the evolved amounts of $\mathrm{H}_{2}$ after $6 \mathrm{~h}$ were 17.7, 206, and 72.4 $\mu \mathrm{mol}$ [the turnover numbers (TONs) were 35,412 , and 145, respectively]; these results showed that K-2 had the highest activity among these samples under the present reaction conditions. Even for 0.6 and $2.0 \mu \mathrm{mol}$ of Re, K-2 exhibited the highest activities; however, the TONs decreased with increasing concentration of rhenium(V) atoms. When the cesium salts of 2 and 3, $\mathrm{Cs}_{14}\left[\mathrm{O}\left\{\mathrm{Re}(\mathrm{OH})\left(\alpha_{2}-\mathrm{P}_{2} \mathrm{~W}_{17} \mathrm{O}_{61}\right)\right\}_{2}\right](\mathrm{Cs}-2)$ [40] and $\mathrm{Cs}_{3.5} \mathrm{H}_{0.5}\left[\mathrm{PW}_{11} \mathrm{ReO}_{40}\right]$ (Cs3) [40], were used as catalysts, the activities decreased compared with those of K-2 and $\mathrm{Me}_{2} \mathrm{NH}_{2}-\mathbf{3}$; however, the activities of Cs-2 were higher than those of Cs-3. These results suggested that the structure dependence was not influenced by the counter ion.

317

318

319

320

Table 1. Hydrogen evolution from methanol catalyzed by rhenium(V)-coordinated polyoxometalates under visible light irradiation ${ }^{\mathrm{a}}$

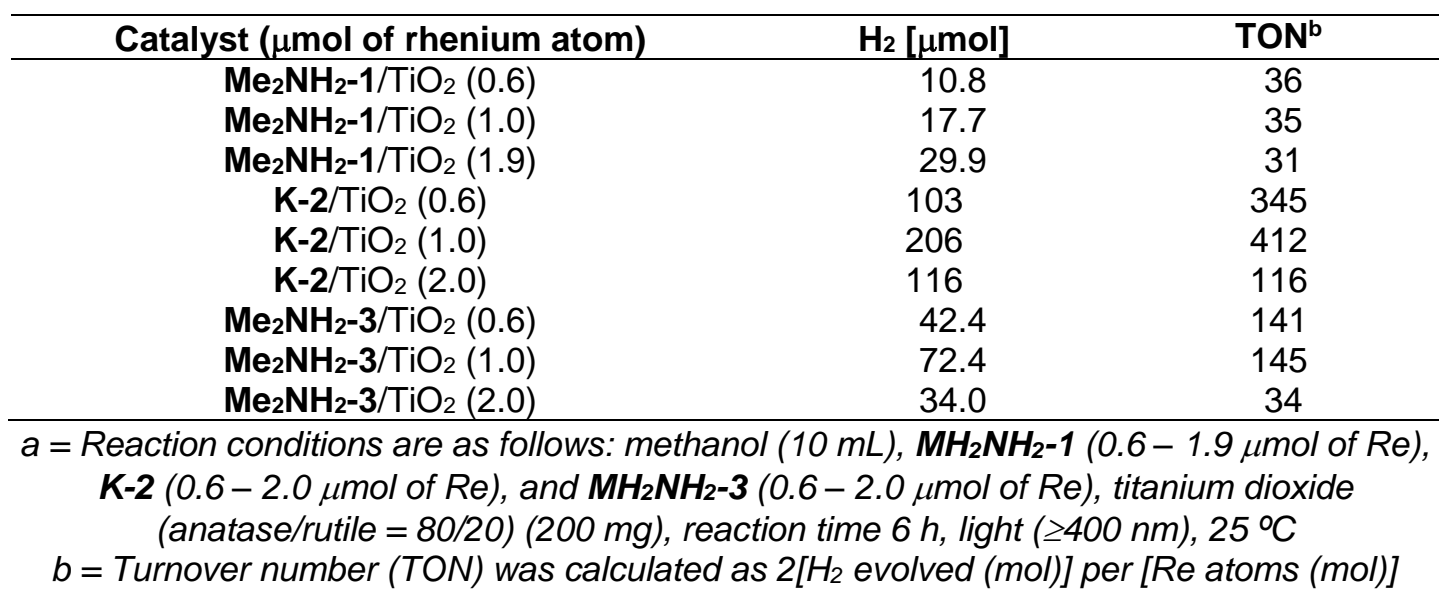

The stabilities of polyoxoanions $\mathbf{1}-\mathbf{3}$ during methanol dehydrogenation were determined by ${ }^{31} \mathrm{P}$ NMR spectroscopy, as follows: $\mathrm{TiO}_{2}(500 \mathrm{mg})$ and the rhenium compounds $(50 \mathrm{mg})$ were suspended in $25 \mathrm{~mL}$ of methanol. After light irradiation for $6 \mathrm{~h}$, the solids were collected using a membrane filter (JG $0.2 \mu \mathrm{m})$. The solids were suspended in $10 \mathrm{~mL}$ of water, and the filtrates, containing dissolved polyoxoanions 1-3, were evaporated to dryness at $40{ }^{\circ} \mathrm{C}$. As shown in Figures 3(b) and 7, the ${ }^{31} \mathrm{P}$ NMR spectra in $\mathrm{CH}_{3} \mathrm{COOLi}-\mathrm{D}_{2} \mathrm{O}$ of $\mathbf{1}$, and in $\mathrm{D}_{2} \mathrm{O}$ of 2 and 3 , were the same as those of the as-prepared samples. This showed that these compounds did not decompose or isomerize during methanol dehydrogenation under light irradiation. It was clear that the rhenium( $(\mathrm{V})$ sites in polyoxometalates significantly affected the photocatalytic activities, and the dirhenium(V)-oxido-bridged site in $\mathbf{2}$ exhibited the highest activity among these three samples under the present reaction conditions. 

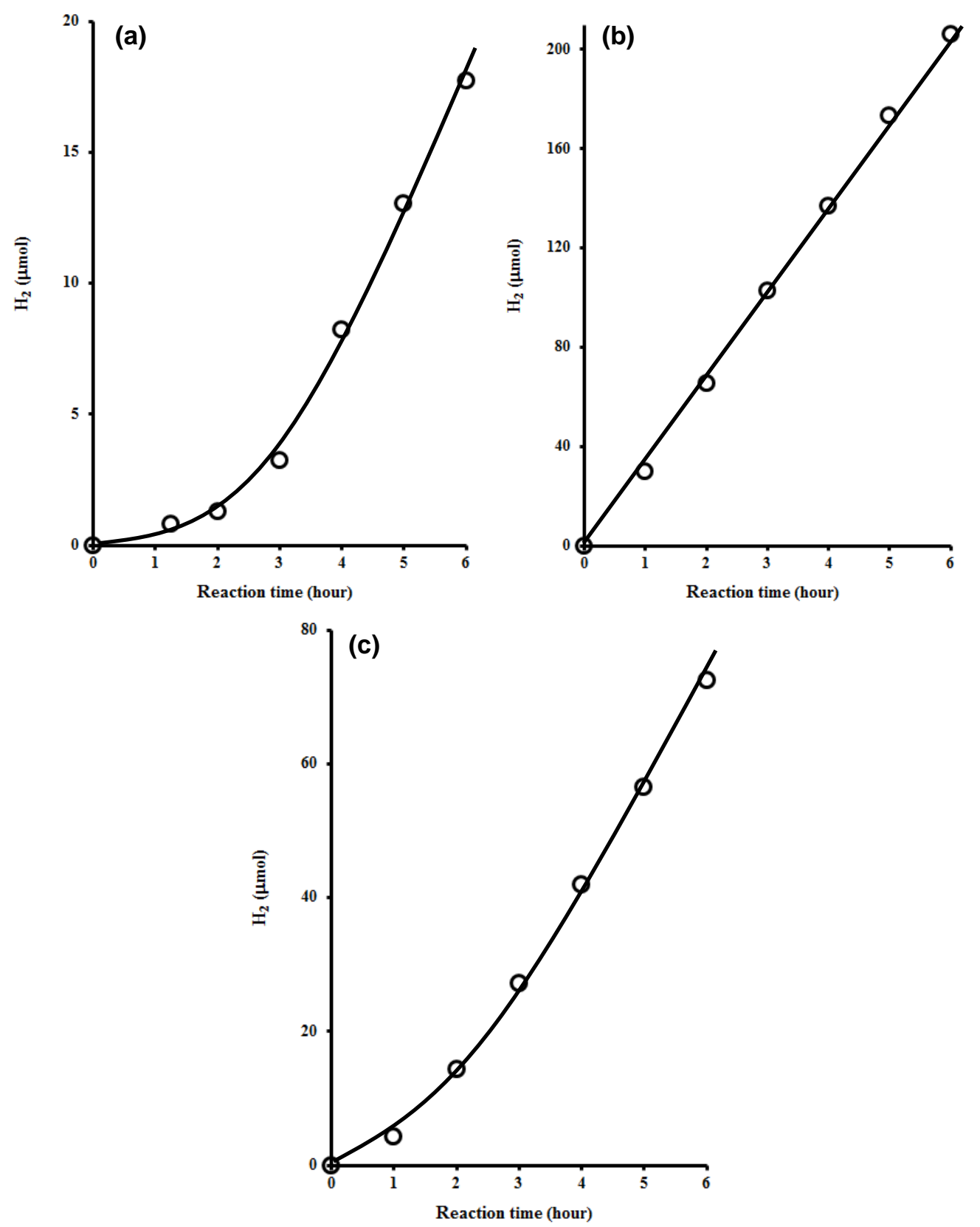

Fig. 6. Time course for methanol dehydrogenation catalyzed by (a) $\mathrm{Me}_{2} \mathrm{NH}_{2}-1$ (1.0 $\mu \mathrm{mol}$ of Re), (b) K-2 (1.0 $\mu \mathrm{mol}$ of Re), and (c) $\mathrm{Me}_{2} \mathrm{NH}_{2}-3(1.0 \mu \mathrm{mol}$ of Re). In this system, the three polyoxotungstates and $\mathrm{TiO}_{2}$ were suspended in methanol, and the visible light $(\geq 400 \mathrm{~nm})$ was irradiated for $6 \mathrm{~h}$ at $25^{\circ} \mathrm{C}$. Reaction conditions are shown in Table 1. 
(a)

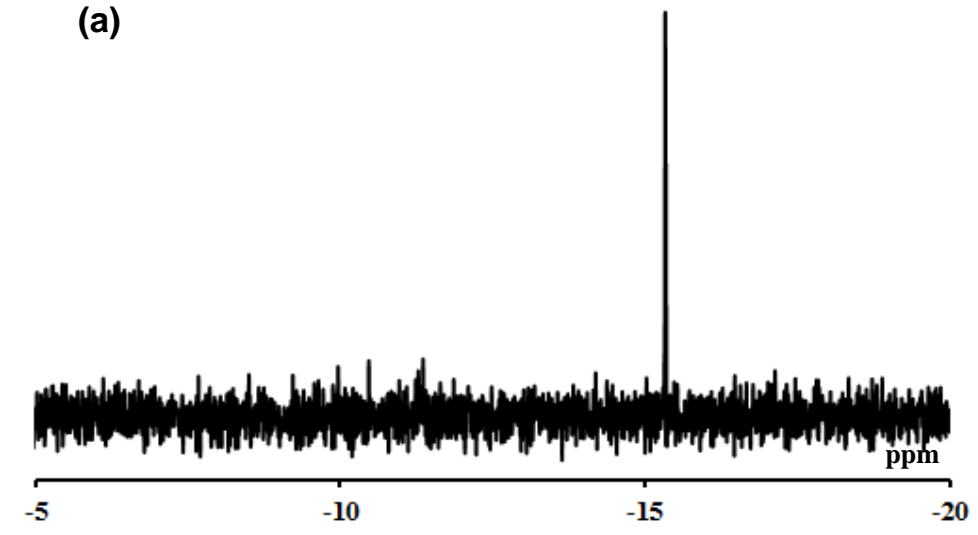

(b)

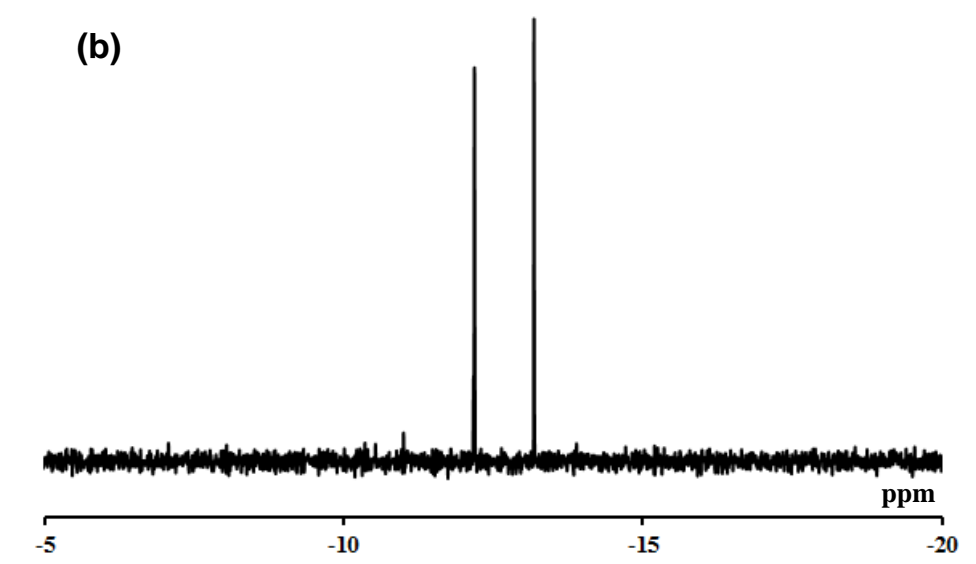

Fig. 7. ${ }^{31} \mathrm{P}$ NMR spectra in $\mathrm{D}_{2} \mathrm{O}$ of (a) $\mathrm{K}-2$ and (b) $\mathrm{Me}_{2} \mathrm{NH}_{2}-3$ after photoreactions. The rhenium compounds $(50 \mathrm{mg})$ and $\mathrm{TiO}_{2}(500 \mathrm{mg})$ were suspended in methanol (25 $\mathrm{mL})$, and they were irradiated under the visible light $(\geq 400 \mathrm{~nm})$ for $6 \mathrm{~h}$.

\section{CONCLUSION}

A rhenium $(\mathrm{V})$ complex composed of mono-lacunary $\alpha_{1}$-Dawson polyoxotungstate was presented. We successfully obtained single crystals of dimethylammonium salt $\left[\mathrm{Me}_{2} \mathrm{NH}_{2}\right]_{7}\left[\alpha_{1}-\mathrm{P}_{2} \mathrm{~W}_{17} \mathrm{Re}^{\vee} \mathrm{O}_{62}\right] \cdot 9 \mathrm{H}_{2} \mathrm{O}\left(\mathrm{Me}_{2} \mathrm{NH}_{2}-1\right)$ by reacting hexachlororhenate with a monolacunary $\alpha_{1}$-Dawson polyoxoanion in $\mathrm{CH}_{3} \mathrm{COOH} / \mathrm{CH}_{3} \mathrm{COOLi}$ buffer, followed by crystallization via vapor diffusion from acetonitrile/ethanol. The characterization of compound $\mathbf{M e}_{2} \mathrm{NH}_{2}-1$ was accomplished by $\mathrm{X}$-ray structure analysis, elemental analysis, TG/DTA, FTIR, UV-visible, and solution ${ }^{31} \mathrm{P}$ NMR spectroscopy. For methanol dehydrogenation under visible light irradiation $(\geq 400 \mathrm{~nm})$ in the presence of $\mathrm{TiO}_{2}$, the molecular structures of three rhenium $(\mathrm{V})$ compounds were stable during the photoreactions, and the dirhenium(V)-oxido-bridged site in 2 exhibited the most effective activities compared with those of the mono-rhenium(V)-substituted sites in $\mathbf{1}$ and $\mathbf{3}$. 


\section{ACKNOWLEDGEMENTS}

370

371

372

373

374

375

376

377

378

379

380

381

382

383

384

385

386

387

388

389

390

391

392

393

394

395

396

397

398

399

400

401

402

403

404

405

406

407

408

409

410

411

412

413

414

415

416

417

418

419

420

This work was supported by a Grant-in-Aid for Scientific Research C (No. 23550150) of the Ministry of Education, Culture, Sports, Science and Technology, Japan.

\section{COMPETING INTERESTS}

Authors have declared that no competing interests exist.

\section{REFERENCES}

1. Fujishima A, Honda K. Electrochemical photolysis of water at a semiconductor electrode. Nature. 1972; 238 37-38.

2. Schiavello M, editor. Heterogeneous photocatalysis. Chichester: John Wiley \& Sons; 1997.

3. Fujishima A, Hashimoto $\mathrm{K}$, Watanabe $\mathrm{T} . \mathrm{TiO}_{2}$ Photocatalysis: Fundamentals and applications. Tokyo: BKC Inc; 1999.

4. Abe R, Recent progress on photocatalytic and photoelectrochemical water splitting under visible light irradiation. J Photochem Photobiol C: Photochem Rev. 2010; 11 179209.

5. Maeda K, Domen K. Photocatalytic water splitting: recent progress and future challenges. J Phys Chem Lett. 2010; 1 2655-2661.

6. Maeda K, Domen K. Surface nanostructures in photocatalysts for visible-light-driven water splitting. Top Curr Chem. 2011; 303 95-119, and references therein.

7. Chatterjee D. Effect of excited state redox properties of dye sensitizers on hydrogen production through photo-splitting water over $\mathrm{TiO}_{2}$ photocatalyst. Catal Commun. 2010; 11 336-339.

8. Zielińska-Jurek A, Kowalska E, Sobczak JW, Lisowski W, Ohtani B, Zaleska A. Preparation and characterization of monometallic( $\mathrm{Au}$ ) and bimetallic( $\mathrm{Ag} / \mathrm{Au})$-modified titania photocatalysts activated by visible light. Appl Catal B: Environ. 2011; 101 504514.

9. Sonawane RS, Dongare MK. Sol-gel synthesis of $\mathrm{Au} / \mathrm{TiO}_{2}$ thin films for photocatalytic degradation of phenol in sun light. J Mol Catal A: Chem. 2006; 243 68-76.

10. Chuang $\mathrm{H}$, Chen $\mathrm{D}$. Fabrication and photocatalytic activities in visible light and UV light regions of Ag@TiO ${ }_{2}$ nanoparticles. Nanotechnology 2009; 20 105704-105714.

11. Li FB, Li XZ. Photocatalytic properties of gold/gold ion-modified titanium dioxide for waste water treatment. Appl Catal A: Gen. 2002; 228 15-27.

12. Seery MK, George R, Floris P, Pillai SC. Silver doped titanium dioxide nanomaterials for enhanced visible light photocatalysis. J Photochem Photobiol A Chem. 2007; 189 258263.

13. Ishibai $\mathrm{Y}$, Sato J, Nishikawa $\mathrm{T}$, Miyagishi S. Synthesis of visible-light-active $\mathrm{TiO}_{2}$ photocatalyst with Pt-modification: Role of $\mathrm{TiO}_{2}$ substrate for high photocatalytic activity. Appl Catal B: Environ 2008; 79 117-121.

14. Kowalska $E$, Abe $R$, Ohtani B. Visible light-induced photocatalytic reaction of goldmodified-titanium(IV) oxide particles: action spectrum analysis. Chem Commun. 2009; 241.

15. Haruta M, Tsubota S, Kobayashi T, Kageyama H, Genet MJ, Delmon B. Lowtemperature oxidation of $\mathrm{CO}$ over gold supported on $\mathrm{TiO}_{2} \alpha-\mathrm{Fe}_{2} \mathrm{O}_{3}$, and $\mathrm{Co}_{3} \mathrm{O}_{4}$. J Catal. 1993; 144 175-192.

16. Kowalska E, Mahaney OOP, Abe R, Ohtani B. Visible-light-induced photocatalysis through surface plasmon excitation of gold on titania surfaces. Phys Chem Chem Phys. 2010;12 2344-2355, and references therein. 
469

470

471

17. Abe R, Hara K, Sayama K, Domen K, Arakawa H, Steady hydrogen evolution from water on Eosin $\mathrm{Y}$-fixed $\mathrm{TiO}_{2}$ photocatalyst using a silane-coupling reagent under visible light irradiation. J Photochem Photobiol A: Chem. 2000; 137 63-69.

18. Li Y, Guo M, Peng S, Lu G, Li S. Formation of multilayer-Eosin Y-sensitized $\mathrm{TiO}_{2}$ via $\mathrm{Fe}^{3+}$ coupling for efficient visible-light photocatalytic hydrogen evolution. Int $\mathrm{J}$ Hydrogen Energy. 2009; 34 5629-5636.

19. Sreethawong $T$, Junbua $\mathrm{C}$, Chavadej $\mathrm{S}$. Photocatalytic $\mathrm{H}_{2}$ production from water splitting under visible light irradiation using Eosin Y-sensitized mesoporous-assembled $\mathrm{Pt} / \mathrm{TiO}_{2}$ nanocrystal photocatalyst. J Power Sources 2009; 190 513-524.

20. Li Y, Xie C, Peng S, Lu G, Li S. Eosin Y-sensitized nitrogen-doped $\mathrm{TiO}_{2}$ for efficient visible light photocatalytic hydrogen evolution. J Mol Catal A: Chem. 2008; 282 117-123.

21. Nada AA, Hamed HA, Barakat MH, Mohamed NR, Veziroglu TN. Enhancement of photocatalytic hydrogen production rate using photosensitized $\mathrm{TiO}_{2} / \mathrm{RuO}_{2}-\mathrm{MV}^{2+}$. Int $\mathrm{J}$ Hydrogen Energy. 2008; 33 3264-3269.

22. O'Regan B, Grätzel M. A low-cost, high-efficiency solar cell based on dye-sensitized colloidal $\mathrm{TiO}_{2}$ films. Nature. 1991; 353 737-740.

23. Borgias BA, Cooper SR, Koh YB, Raymond KN. Synthetic, structural, and physical studies of titanium complexes of catechol and 3,5-di-tert-butylcatechol. Inorg Chem. 1984; 23 1009-1016.

24. Liu Y, Dadap JI, Zimdars D, Eisenthal KB. Study of interfacial charge-transfer complex on $\mathrm{TiO}_{2}$ particles in aqueous suspension by second-harmonic generation. $\mathrm{J}$ Phys Chem B 1999; 103 2480-2486.

25. Rodriguez $R$, Blesa MA, Regazzoni AE. Surface complexation at the $\mathrm{TiO}_{2}$ (anatase)/aqueous solution interface: chemisorptions of catechol. J Colloid Interface Sci. 1996; 177 122-131.

26. Moser J, Punchihewa S, Infelta PP, Grätzel M. Surface complexation of colloidal semiconductors strongly enhances interfacial electron-transfer rates. Langmuir. 1991; 7 3012-3018.

27. Regazzoni AE, Mandelbaum $P$, Matsuyoshi M, Schiller S, Bilmes SA, Blesa MA. Adsorption and photooxidaiton of salicylic acid on titanium dioxide: a surface complexation description. Langmuir. 1998; 14 868-874.

28. Ikeda S, Abe C, Torimoto T, Ohtani B. Visible light-induced hydrogen evolution from aqueous suspension of titanium(IV) oxide modified with binaphthol. Electrochem. 2002; 70(6) 442-445.

29. Ikeda S, Abe C, Torimoto T, Ohtani B. Photochemical hydrogen evolution from aqueous triethanolamine solutions sensitized by binaphthol-modified titanium(IV) oxide under visible-light irradiation. J Photochem Photobiol A: Chem. 2003;160 61-67, and references therein.

30. Pope MT. Heteropoly and isopoly oxometalates. New York: Springer-Verlag; 1983.

31. Pope MT, Müller A. Chemistry of polyoxometalates. Actual variation on an old theme with interdisciplinary references. Angew Chem Int Ed Engl. 1991; 30 34-48.

32. Pope MT, Müller A, editors; Polyoxometalates: from platonic solids to anti-retroviral activity. Dordrecht, The Netherlands: Kluwer Academic Publishers; 1994.

33. Dubey N, Labhsetwar NK, Devotta S, Rayalu SR. Hydrogen evolution by water splitting using novel composite zeolite-based photocatalyst. Catal Today. 2007;129 428-434.

34. Najafabadi AT, Taghipour F. Cobalt precursor role in the photocatalytic activity of the zeolite-supported $\mathrm{TiO}_{2}$-based photocatalysts under visible light: a promising tool toward zeolite-based core-shell photocatalysis. J Photochem Photobiol A: Chem. 2012; 248 17.

35. Fu N, Lu G. Graft of lacunary Wells-Dawson heteropoly blue on the surface of $\mathrm{TiO}_{2}$ and its photocatalytic activity under visible light. Chem Commun. 2009; 3591-3593. 
36. Fu N, Wu Y, Jin Z, Lu G. Structural-dependent photoactivities of $\mathrm{TiO}_{2}$ nanoribbon for visible-light-induced $\mathrm{H}_{2}$ evolution: the roles of nanocavities and alternate structures. Langmuir 2010; 26(1) 447-455.

37. Fu N, Lu G. Photo-catalytic $\mathrm{H}_{2}$ evolution over a series of Keggin-structure heteropoly bule sensitized $\mathrm{Pt} / \mathrm{TiO}_{2}$ under visible light irradiation. Appl Surf Sci. 2009; 255 43784383.

38. Sivakumer R, Thomas J, Yoon M. Polyoxometalate-based molecular/nano composites: advances in environmental remediation by photocatalysis and biomimetic approaches to solar energy conversion. J Photochem Photobiol C: Photochem Rev. 2012; 13 277298.

39. Kato CN, Hara K, Hatano A, Goto K, Kuribayashi T, Hayashi K, et al. A Dawson-type dirhenium(V)-oxido-bridged polyoxotungstate: X-ray crystal structure and hydrogen evolution from water vapor under visible light irradiation. Eur J Inorg Chem. 2008; 31343141.

40. Kato CN, Hara K, Kato M, Amano H, Sato K, Kataoka Y, et al. EDTA-reduction of water to molecular hydrogen catalyzed by visible-light-response $\mathrm{TiO}_{2}$-based materials sensitized by Dawson- and Keggin-type rhenium(V)-containing polyoxotungstates. Materials. 2010; 3 897-917.

41. Contant R. Potassium octadecatungstodiphosphates $(\mathrm{V})$ and related lacunary compounds. Inorg Synth. 1990; 27 104-110.

42. Lyon DK, Miller WK, Novet T, Domaille PJ, Evitt E, Johnson DC, Finke RG. Highly oxidation resistant inorganic-porphyrin analogue polyoxometalate oxidation catalysts. the synthesis and characterization of aqueous-soluble potassium salts of $\alpha_{2}$ $\mathrm{P}_{2} \mathrm{~W}_{17} \mathrm{O}_{61}\left(\mathrm{M}^{\mathrm{n}+} \cdot \mathrm{OH}_{2}\right)^{(\mathrm{n}-10)}$ and organic solvent soluble tetra-n-butylammonium salts of $\alpha_{2}-$ $\mathrm{P}_{2} \mathrm{~W}_{17} \mathrm{O}_{61}\left(\mathrm{M}^{\mathrm{n}+} \cdot \mathrm{Br}\right)^{(\mathrm{n}-11)}\left(\mathrm{M}=\mathrm{Mn}^{3+}, \mathrm{Fe}^{3+}, \mathrm{Co}^{2+}, \mathrm{Ni}^{2+}, \mathrm{Cu}^{2+}\right)$. J Am Chem Soc. 1991; 113 7209-7221.

43. Weiner $\mathrm{H}$, Aiken III JD, Finke RG. Polyoxometalate catalyst precursors. improved synthesis, $\mathrm{H}^{+}$-titration procedure, and evidence for ${ }^{31} \mathrm{P}$ NMR as a highly sensitive support-site indication for the prototype polyoxoanion-organometallic-support system $\left[\left(\mathrm{n}-\mathrm{C}_{4} \mathrm{H}_{9}\right)_{4} \mathrm{~N}_{9} \mathrm{P}_{2} \mathrm{~W}_{15} \mathrm{Nb}_{3} \mathrm{O}_{62}\right.$. Inorg Chem. 1996; 35 7905-7913.

44. Sheldrick GM. A short history of SHELX. Acta Crystallogr. 2008; A64 112-122.

45. Spek AL. Structure validation in chemical crystallography. Acta Crystallogr. 2009; D65 148-155.

46. Nash T. The colorimetric estimation of formaldehyde by means of the hantzsch reaction. Biochem J. 1953; 55 416-421.

47. Ortéga F, Pope MT, Evans, Jr HT. Tungstorhenate heteropolyanions. 2. Synthesis and characterization of enneatungstorhenates $(\mathrm{V}),-(\mathrm{VI})$, and $-(\mathrm{VII})$. Inorg Chem. 1997; 36 2166-2169.

48. Kato CN, Makino Y, Yamasaki M, Kataoka Y, Kitagawa Y, Okumura M. Synthesis and $X$-ray crystal structure of $\alpha$-Keggin-type aluminum-substituted polyoxotungstate. In: Mastai Y editor. Advances in crystallization processes. Croatia: InTech; 2012.

\section{APPENDIX}

Bond lengths (Å) of $\mathrm{Me}_{2} \mathrm{NH}_{2}-1$ : $\operatorname{Re}(1)(\mathrm{W}(4))-\mathrm{O}(8)$ 1.915(14); $\operatorname{Re}(1)(\mathrm{W}(4))-\mathrm{O}(14)$ 1.702(14); $\operatorname{Re}(1)(\mathrm{W}(4))-\mathrm{O}(19)$ 1.912(16); $\operatorname{Re}(1)(\mathrm{W}(4))-\mathrm{O}(20)$ 1.870(17); $\operatorname{Re}(1)(\mathrm{W}(4))-\mathrm{O}(26) 2.374(12) ;$ $\operatorname{Re}(1)(\mathrm{W}(4))-\mathrm{O}(57)$ 1.896(12); $\operatorname{Re}(2)(\mathrm{W}(5))-\mathrm{O}(9)$ 1.968(13); $\operatorname{Re}(2)(\mathrm{W}(5))-\mathrm{O}(15)$ 1.733(13); $\operatorname{Re}(2)(\mathrm{W}(5))-\mathrm{O}(20)$ 1.900(18); $\operatorname{Re}(2)(\mathrm{W}(5))-\mathrm{O}(21)$ 1.928(17); $\operatorname{Re}(2)(\mathrm{W}(5))-\mathrm{O}(27)$ 2.353(12); $\operatorname{Re}(2)(\mathrm{W}(5))-\mathrm{O}(58)$ 1.889(13); $\operatorname{Re}(3)(\mathrm{W}(6))-\mathrm{O}(10)$ 1.951(14); $\operatorname{Re}(3)(\mathrm{W}(6))-\mathrm{O}(16)$ 1.696(18); $\operatorname{Re}(3)(\mathrm{W}(6))-\mathrm{O}(21)$ 1.896(12); $\operatorname{Re}(3)(\mathrm{W}(6))-\mathrm{O}(22)$ 1.909(13); $\operatorname{Re}(3)(\mathrm{W}(6))-\mathrm{O}(27)$ 2.376(18); $\operatorname{Re}(3)(\mathrm{W}(6))-\mathrm{O}(59)$ 1.924(13); $\operatorname{Re}(4)(\mathrm{W}(7))-\mathrm{O}(11)$ 1.968(12); $\operatorname{Re}(4)(\mathrm{W}(7))-\mathrm{O}(17)$ 1.714(16); $\operatorname{Re}(4)(\mathrm{W}(7))-\mathrm{O}(22)$ 1.877(14); $\operatorname{Re}(4)(\mathrm{W}(7))-\mathrm{O}(23)$ 1.929(16); $\operatorname{Re}(4)(\mathrm{W}(7))-\mathrm{O}(28)$ 2.353(15); 
$525 \quad \operatorname{Re}(4)(\mathrm{W}(7))-\mathrm{O}(60)$ 1.893(13); $\operatorname{Re}(5)(\mathrm{W}(8))-\mathrm{O}(12)$ 1.951(13); $\operatorname{Re}(5)(\mathrm{W}(8))-\mathrm{O}(18)$ 1.689(14); $526 \quad \operatorname{Re}(5)(\mathrm{W}(8))-\mathrm{O}(23)$ 1.891(17); $\operatorname{Re}(5)(\mathrm{W}(8))-\mathrm{O}(24)$ 1.906(15); $\operatorname{Re}(5)(\mathrm{W}(8))-\mathrm{O}(28)$ 2.360(13); $527 \quad \operatorname{Re}(5)(\mathrm{W}(8))-\mathrm{O}(61)$ 1.881(12); $\operatorname{Re}(6)(\mathrm{W}(9))-\mathrm{O}(7)$ 1.905(14); $\operatorname{Re}(6)(\mathrm{W}(9))-\mathrm{O}(13)$ 1.691(17); $528 \quad \operatorname{Re}(6)(\mathrm{W}(9))-\mathrm{O}(19)$ 1.899(13); $\operatorname{Re}(6)(\mathrm{W}(9))-\mathrm{O}(24)$ 1.866(13); $\operatorname{Re}(6)(\mathrm{W}(9))-\mathrm{O}(26)$ 2.379(16); $529 \quad \operatorname{Re}(6)(\mathrm{W}(9))-\mathrm{O}(62) 1.924(14) ; \operatorname{Re}(7)(\mathrm{W}(10))-\mathrm{O}(30)$ 1.708(16); $\operatorname{Re}(7)(\mathrm{W}(10))-\mathrm{O}(35)$ 1.916(16); $530 \quad \operatorname{Re}(7)(\mathrm{W}(10))-\mathrm{O}(36) \quad 1.863(16) ; \operatorname{Re}(7)(\mathrm{W}(10))-\mathrm{O}(42) \quad 1.943(12) ; \quad \operatorname{Re}(7)(\mathrm{W}(10))-\mathrm{O}(54)$ $531 \quad 2.360(12) ; \operatorname{Re}(7)(\mathrm{W}(10))-\mathrm{O}(57)$ 1.919(12); $\operatorname{Re}(8)(\mathrm{W}(11))-\mathrm{O}(31)$ 1.734(14); $\operatorname{Re}(8)(\mathrm{W}(11))-$ $532 \quad \mathrm{O}(36) \quad 1.911(15) ; \quad \operatorname{Re}(8)(\mathrm{W}(11))-\mathrm{O}(37) \quad 1.884(16) ; \quad \operatorname{Re}(8)(\mathrm{W}(11))-\mathrm{O}(43) \quad 1.960(15) ;$ $533 \quad \operatorname{Re}(8)(\mathrm{W}(11))-\mathrm{O}(55) \quad 2.385(11) ; \quad \operatorname{Re}(8)(\mathrm{W}(11))-\mathrm{O}(58) \quad 1.881(14) ; \quad \operatorname{Re}(9)(\mathrm{W}(12))-\mathrm{O}(32)$ $534 \quad 1.689(18) ; \operatorname{Re}(9)(\mathrm{W}(12))-\mathrm{O}(37)$ 1.941(12); $\operatorname{Re}(9)(\mathrm{W}(12))-\mathrm{O}(38)$ 1.879(12); $\operatorname{Re}(9)(\mathrm{W}(12))-$ $535 \quad \mathrm{O}(44) \quad 1.968(14) ; \quad \operatorname{Re}(9)(\mathrm{W}(12))-\mathrm{O}(55) \quad 2.345(16) ; \quad \operatorname{Re}(9)(\mathrm{W}(12))-\mathrm{O}(59) \quad 1.861(13) ;$ $536 \quad \operatorname{Re}(10)(\mathrm{W}(13))-\mathrm{O}(33) \quad 1.694(15) ; \quad \operatorname{Re}(10)(\mathrm{W}(13))-\mathrm{O}(38)$ 1.892(13); $\operatorname{Re}(10)(\mathrm{W}(13))-\mathrm{O}(39)$ 537 1.902(16); $\operatorname{Re}(10)(\mathrm{W}(13))-\mathrm{O}(45)$ 1.981(14); $\operatorname{Re}(10)(\mathrm{W}(13))-\mathrm{O}(56)$ 2.351(14); $\operatorname{Re}(10)(\mathrm{W}(13))-$ $538 \quad \mathrm{O}(60) \quad 1.890(13) ; \quad \operatorname{Re}(11)(\mathrm{W}(14))-\mathrm{O}(34) \quad 1.701(15) ; \quad \operatorname{Re}(11)(\mathrm{W}(14))-\mathrm{O}(39) \quad 1.897(17) ;$ $539 \quad \operatorname{Re}(11)(\mathrm{W}(14))-\mathrm{O}(40) \quad 1.872(14) ; \quad \operatorname{Re}(11)(\mathrm{W}(14))-\mathrm{O}(46) \quad 1.980(13) ; \quad \operatorname{Re}(11)(\mathrm{W}(14))-\mathrm{O}(56)$ $540 \quad$ 2.374(13); $\operatorname{Re}(11)(\mathrm{W}(14))-\mathrm{O}(61)$ 1.891(13); $\operatorname{Re}(12)(\mathrm{W}(15))-\mathrm{O}(29)$ 1.679(19); $\operatorname{Re}(12)(\mathrm{W}(15))-$ $541 \quad \mathrm{O}(35) \quad 1.907(12) ; \quad \operatorname{Re}(12)(\mathrm{W}(15))-\mathrm{O}(40) \quad 1.899(13) ; \quad \operatorname{Re}(12)(\mathrm{W}(15))-\mathrm{O}(41) \quad 1.958(13) ;$ $542 \quad \operatorname{Re}(12)(\mathrm{W}(15))-\mathrm{O}(54)$ 2.384(16); $\operatorname{Re}(12)(\mathrm{W}(15))-\mathrm{O}(62)$ 1.867(13); $\mathrm{W}(1)-\mathrm{O}(1)$ 1.690(11); $\mathrm{W}(1)-$ $543 \quad \mathrm{O}(4)$ 1.921(15); W(1)-O(5) 1.910(15); W(1)-O(8) 1.912(16); W(1)-O(9) 1.870(14); W(1)-O(25) $544 \quad 2.402(11) ; \mathrm{W}(2)-\mathrm{O}(2)$ 1.705(16); W(2)-O(5) 1.902(11); W(2)-O(6) 1.920(17); W(2)-O(10) 545 1.880(15); W(2)-O(11) 1.882(12); W(2)-O(25) 2.364(15); W(3)-O(3) 1.692(14); W(3)-O(4) $546 \quad 1.915(12) ; \mathrm{W}(3)-\mathrm{O}(6)$ 1.887(18); W(3)-O(7) 1.918(16); W(3)-O(12) 1.874(12); W(3)-O(25) 547 2.386(13); W(16)-O(42) 1.892(15); W(16)-O(43) 1.874(17); W(16)-O(47) 1.730(14); W(16)$548 \quad \mathrm{O}(50)$ 1.908(15); $\mathrm{W}(16)-\mathrm{O}(51)$ 1.932(15); $\mathrm{W}(16)-\mathrm{O}(53) 2.415(12) ; \mathrm{W}(17)-\mathrm{O}(44)$ 1.865(15); $549 \quad \mathrm{~W}(17)-\mathrm{O}(45) \quad 1.865(13) ; \mathrm{W}(17)-\mathrm{O}(48)$ 1.680(14); $\mathrm{W}(17)-\mathrm{O}(51)$ 1.898(14); $\mathrm{W}(17)-\mathrm{O}(52)$ 550 1.932(17); W(17)-O(53) 2.352(13); W(18)-O(41) 1.886(14); W(18)-O(46) 1.877(13); W(18)$551 \quad \mathrm{O}(49)$ 1.705(16); $\mathrm{W}(18)-\mathrm{O}(50)$ 1.966(12); W(18)-O(52) 1.900(17); W(18)-O(53) 2.354(14); $552 \quad \mathrm{P}(1)-\mathrm{O}(25)$ 1.593(12); $\mathrm{P}(1)-\mathrm{O}(26)$ 1.494(17); $\mathrm{P}(1)-\mathrm{O}(27)$ 1.517(16); $\mathrm{P}(1)-\mathrm{O}(28)$ 1.543(12); $553 \quad \mathrm{P}(2)-\mathrm{O}(53)$ 1.600(12); $\mathrm{P}(2)-\mathrm{O}(54)$ 1.500(15); $\mathrm{P}(2)-\mathrm{O}(55)$ 1.514(16); $\mathrm{P}(2)-\mathrm{O}(56)$ 1.531(12).

554

555

556

557

558

559

560

561

562

563

564

565

566

567

568

569

570

571

572

573

574

575

576

577

Bond angles ( $\left.{ }^{\circ}\right)$ of $\mathbf{M e}_{2} \mathbf{N H}_{2}-1$ : $\mathrm{O}(8)-\operatorname{Re}(1)(\mathrm{W}(4))-\mathrm{O}(14)$ 97.6(6); $\mathrm{O}(8)-\operatorname{Re}(1)(\mathrm{W}(4))-\mathrm{O}(19)$ 89.9(7); O(8)-Re(1)(W(4))-O(20) 85.3(7); O(8)-Re(1)(W(4))-O(26) 81.4(5); O(8)-Re(1)(W(4))$\mathrm{O}(57)$ 164.6(6); O(14)-Re(1)(W(4))-O(19) 99.4(7); O(14)-Re(1)(W(4))-O(20) 103.4(7); O(14)$\operatorname{Re}(1)(\mathrm{W}(4))-\mathrm{O}(26) \quad 172.2(7) ; \quad \mathrm{O}(14)-\operatorname{Re}(1)(\mathrm{W}(4))-\mathrm{O}(57) \quad 97.7(6) ; \quad \mathrm{O}(19)-\operatorname{Re}(1)(\mathrm{W}(4))-\mathrm{O}(20)$ 157.1(6); O(19)-Re(1)(W(4))-O(26) 72.9(6); O(19)-Re(1)(W(4))-O(57) 89.4(6); O(20)$\operatorname{Re}(1)(\mathrm{W}(4))-\mathrm{O}(26) \quad 84.3(6) ; \quad \mathrm{O}(20)-\operatorname{Re}(1)(\mathrm{W}(4))-\mathrm{O}(57) \quad 89.5(6) ; \quad \mathrm{O}(26)-\operatorname{Re}(1)(\mathrm{W}(4))-\mathrm{O}(57)$ 83.7(5); O(9)-Re(2)(W(5))-O(15) 97.4(6); O(9)-Re(2)(W(5))-O(20) 84.8(7); O(9)-Re(2)(W(5))$\mathrm{O}(21)$ 88.1(6); O(9)-Re(2)(W(5))-O(27) 81.8(5); O(9)-Re(2)(W(5))-O(58) 163.3(6); O(15)$\operatorname{Re}(2)(\mathrm{W}(5))-\mathrm{O}(20) \quad 102.0(7) ; \quad \mathrm{O}(15)-\operatorname{Re}(2)(\mathrm{W}(5))-\mathrm{O}(21) \quad 99.5(7) ; \quad \mathrm{O}(15)-\operatorname{Re}(2)(\mathrm{W}(5))-\mathrm{O}(27)$ 173.0(8); O(15)- $\operatorname{Re}(2)(\mathrm{W}(5))-\mathrm{O}(58) \quad 99.1(6) ; \quad \mathrm{O}(20)-\operatorname{Re}(2)(\mathrm{W}(5))-\mathrm{O}(21) \quad 158.1(6) ; \quad \mathrm{O}(20)-$ $\operatorname{Re}(2)(\mathrm{W}(5))-\mathrm{O}(27) \quad 84.9(6) ; \quad \mathrm{O}(20)-\operatorname{Re}(2)(\mathrm{W}(5))-\mathrm{O}(58) \quad 89.5(7) ; \quad \mathrm{O}(21)-\operatorname{Re}(2)(\mathrm{W}(5))-\mathrm{O}(27)$ 73.5(6); $\mathrm{O}(21)-\operatorname{Re}(2)(\mathrm{W}(5))-\mathrm{O}(58) \quad 91.4(7) ; \quad \mathrm{O}(27)-\operatorname{Re}(2)(\mathrm{W}(5))-\mathrm{O}(58) \quad 82.1(5) ; \quad \mathrm{O}(10)-$ $\operatorname{Re}(3)(\mathrm{W}(6))-\mathrm{O}(16) \quad 98.5(7) ; \quad \mathrm{O}(10)-\operatorname{Re}(3)(\mathrm{W}(6))-\mathrm{O}(21) \quad 88.0(6) ; \quad \mathrm{O}(10)-\operatorname{Re}(3)(\mathrm{W}(6))-\mathrm{O}(22)$ 86.8(6); O(10)-Re(3)(W(6))-O(27) 81.4(7); O(10)-Re(3)(W(6))-O(59) 163.6(8); O(16)$\operatorname{Re}(3)(\mathrm{W}(6))-\mathrm{O}(21) \quad 100.1(7) ; \mathrm{O}(16)-\operatorname{Re}(3)(\mathrm{W}(6))-\mathrm{O}(22) \quad 102.0(7) ; \mathrm{O}(16)-\operatorname{Re}(3)(\mathrm{W}(6))-\mathrm{O}(27)$ 173.7(5); O(16)- $\operatorname{Re}(3)(\mathrm{W}(6))-\mathrm{O}(59) \quad 97.8(7) ; \quad \mathrm{O}(21)-\operatorname{Re}(3)(\mathrm{W}(6))-\mathrm{O}(22) \quad 157.7(8) ; \quad \mathrm{O}(21)-$ $\operatorname{Re}(3)(\mathrm{W}(6))-\mathrm{O}(27) \quad 73.5(6) ; \quad \mathrm{O}(21)-\operatorname{Re}(3)(\mathrm{W}(6))-\mathrm{O}(59) \quad 90.8(6) ; \quad \mathrm{O}(22)-\operatorname{Re}(3)(\mathrm{W}(6))-\mathrm{O}(27)$ 84.3(7); $\mathrm{O}(22)-\operatorname{Re}(3)(\mathrm{W}(6))-\mathrm{O}(59) \quad 88.1(6) ; \quad \mathrm{O}(27)-\operatorname{Re}(3)(\mathrm{W}(6))-\mathrm{O}(59) \quad 82.6(6) ; \quad \mathrm{O}(11)-$ $\operatorname{Re}(4)(\mathrm{W}(7))-\mathrm{O}(17) \quad 96.9(6) ; \quad \mathrm{O}(11)-\operatorname{Re}(4)(\mathrm{W}(7))-\mathrm{O}(22) \quad 86.0(6) ; \quad \mathrm{O}(11)-\operatorname{Re}(4)(\mathrm{W}(7))-\mathrm{O}(23)$ 87.8(6); O(11)- $\operatorname{Re}(4)(\mathrm{W}(7))-\mathrm{O}(28) \quad 81.7(6) ; \quad \mathrm{O}(11)-\operatorname{Re}(4)(\mathrm{W}(7))-\mathrm{O}(60) \quad 163.4(6) ; \quad \mathrm{O}(17)-$ $\operatorname{Re}(4)(\mathrm{W}(7))-\mathrm{O}(22) \quad 102.7(8) ; \quad \mathrm{O}(17)-\operatorname{Re}(4)(\mathrm{W}(7))-\mathrm{O}(23) \quad 99.3(7) ; \quad \mathrm{O}(17)-\operatorname{Re}(4)(\mathrm{W}(7))-\mathrm{O}(28)$ 172.2(6); O(17)- $\operatorname{Re}(4)(\mathrm{W}(7))-\mathrm{O}(60) \quad 99.6(6) ; \quad \mathrm{O}(22)-\operatorname{Re}(4)(\mathrm{W}(7))-\mathrm{O}(23) \quad 157.7(7) ; \quad \mathrm{O}(22)-$ $\operatorname{Re}(4)(\mathrm{W}(7))-\mathrm{O}(28) \quad 84.9(6) ; \quad \mathrm{O}(22)-\operatorname{Re}(4)(\mathrm{W}(7))-\mathrm{O}(60) \quad 89.1(6) ; \quad \mathrm{O}(23)-\operatorname{Re}(4)(\mathrm{W}(7))-\mathrm{O}(28)$ 
73.0(6); O(23)-Re(4)(W(7))-O(60) 90.8(6); O(28)-Re(4)(W(7))-O(60) 82.1(6); O(12)$579 \quad \operatorname{Re}(5)(\mathrm{W}(8))-\mathrm{O}(18) \quad 97.7(6) ; \quad \mathrm{O}(12)-\operatorname{Re}(5)(\mathrm{W}(8))-\mathrm{O}(23) \quad 89.1(7) ; \quad \mathrm{O}(12)-\operatorname{Re}(5)(\mathrm{W}(8))-\mathrm{O}(24)$ $580 \quad 84.5(6) ; \quad \mathrm{O}(12)-\operatorname{Re}(5)(\mathrm{W}(8))-\mathrm{O}(28) \quad 81.5(5) ; \quad \mathrm{O}(12)-\operatorname{Re}(5)(\mathrm{W}(8))-\mathrm{O}(61) \quad 162.6(5) ; \quad \mathrm{O}(18)-$ $581 \quad \operatorname{Re}(5)(\mathrm{W}(8))-\mathrm{O}(23) \quad 99.0(7) ; \quad \mathrm{O}(18)-\operatorname{Re}(5)(\mathrm{W}(8))-\mathrm{O}(24) \quad 102.5(7) ; \quad \mathrm{O}(18)-\operatorname{Re}(5)(\mathrm{W}(8))-\mathrm{O}(28)$ 172.4(7); $\mathrm{O}(18)-\operatorname{Re}(5)(\mathrm{W}(8))-\mathrm{O}(61) \quad 99.3(6) ; \quad \mathrm{O}(23)-\operatorname{Re}(5)(\mathrm{W}(8))-\mathrm{O}(24) \quad 158.3(6) ; \quad \mathrm{O}(23)-$ $\operatorname{Re}(5)(\mathrm{W}(8))-\mathrm{O}(28) \quad 73.5(6) ; \quad \mathrm{O}(23)-\operatorname{Re}(5)(\mathrm{W}(8))-\mathrm{O}(61) \quad 91.9(7) ; \quad \mathrm{O}(24)-\operatorname{Re}(5)(\mathrm{W}(8))-\mathrm{O}(28)$ 85.1(6); O(24)- $\operatorname{Re}(5)(\mathrm{W}(8))-\mathrm{O}(61) \quad 88.3(6) ; \quad \mathrm{O}(28)-\operatorname{Re}(5)(\mathrm{W}(8))-\mathrm{O}(61) \quad 82.1(5) ; \quad \mathrm{O}(7)-$ $\operatorname{Re}(6)(\mathrm{W}(9))-\mathrm{O}(13) \quad 97.4(7) ; \quad \mathrm{O}(7)-\operatorname{Re}(6)(\mathrm{W}(9))-\mathrm{O}(19) \quad 89.2(6) ; \quad \mathrm{O}(7)-\operatorname{Re}(6)(\mathrm{W}(9))-\mathrm{O}(24)$ 87.0(6); O(7)-Re(6)(W(9))-O(26) 81.7(6); O(7)-Re(6)(W(9))-O(62) 163.7(7); O(13)$\operatorname{Re}(6)(\mathrm{W}(9))-\mathrm{O}(19) \quad 100.8(7) ; \mathrm{O}(13)-\operatorname{Re}(6)(\mathrm{W}(9))-\mathrm{O}(24) \quad 101.6(7) ; \mathrm{O}(13)-\operatorname{Re}(6)(\mathrm{W}(9))-\mathrm{O}(26)$ 173.7(5); O(13)- $\operatorname{Re}(6)(\mathrm{W}(9))-\mathrm{O}(62) \quad 98.9(7) ; \quad \mathrm{O}(19)-\operatorname{Re}(6)(\mathrm{W}(9))-\mathrm{O}(24) \quad 157.6(8) ; \quad \mathrm{O}(19)-$ $\operatorname{Re}(6)(\mathrm{W}(9))-\mathrm{O}(26) \quad 73.0(6) ; \quad \mathrm{O}(19)-\operatorname{Re}(6)(\mathrm{W}(9))-\mathrm{O}(62) \quad 88.2(6) ; \quad \mathrm{O}(24)-\operatorname{Re}(6)(\mathrm{W}(9))-\mathrm{O}(26)$ 84.6(6); O(24)-Re(6)(W(9))-O(62) 89.2(6); O(26)-Re(6)(W(9))-O(62) 82.1(6); O(30)$\operatorname{Re}(7)(\mathrm{W}(10))-\mathrm{O}(35)$ 99.4(8); O(30)-Re(7)(W(10))-O(36) 103.2(7); O(30)-Re(7)(W(10))-O(42) 96.7(6); O(30)-Re(7)(W(10))-O(54) 172.0(7); O(30)-Re(7)(W(10))-O(57) 99.0(6); O(35)$\operatorname{Re}(7)(\mathrm{W}(10))-\mathrm{O}(36)$ 157.2(6); O(35)- $\operatorname{Re}(7)(\mathrm{W}(10))-\mathrm{O}(42)$ 87.2(6); O(35)- $\operatorname{Re}(7)(\mathrm{W}(10))-\mathrm{O}(54)$ 72.8(6); O(35)- $\operatorname{Re}(7)(\mathrm{W}(10))-\mathrm{O}(57) \quad 88.4(6) ; \quad \mathrm{O}(36)-\operatorname{Re}(7)(\mathrm{W}(10))-\mathrm{O}(42) \quad 87.4(6) ; \quad \mathrm{O}(36)-$ $\operatorname{Re}(7)(\mathrm{W}(10))-\mathrm{O}(54)$ 84.5(5); O(36)- $\operatorname{Re}(7)(\mathrm{W}(10))-\mathrm{O}(57)$ 90.8(6); O(42)- $\operatorname{Re}(7)(\mathrm{W}(10))-\mathrm{O}(54)$ 81.2(5); O(42)-Re(7)(W(10))-O(57) 164.2(6); O(54)-Re(7)(W(10))-O(57) 82.9(5); O(31)$\mathrm{Re}(8)(\mathrm{W}(11))-\mathrm{O}(36)$ 102.7(7); O(31)- $\mathrm{Re}(8)(\mathrm{W}(11))-\mathrm{O}(37)$ 99.2(7); O(31)-Re(8)(W(11))-O(43) 98.5(7); O(31)-Re(8)(W(11))-O(55) 172.6(8); O(31)-Re(8)(W(11))-O(58) 98.3(6); O(36)$\operatorname{Re}(8)(\mathrm{W}(11))-\mathrm{O}(37)$ 158.1(5); O(36)- $\operatorname{Re}(8)(\mathrm{W}(11))-\mathrm{O}(43)$ 85.7(7); O(36)-Re(8)(W(11))-O(55) 84.8(5); O(36)- $\operatorname{Re}(8)(\mathrm{W}(11))-\mathrm{O}(58) \quad 86.6(7) ; \quad \mathrm{O}(37)-\operatorname{Re}(8)(\mathrm{W}(11))-\mathrm{O}(43) \quad 90.8(7) ; \quad \mathrm{O}(37)-$ $\operatorname{Re}(8)(\mathrm{W}(11))-\mathrm{O}(55)$ 73.4(6); O(37)- $\operatorname{Re}(8)(\mathrm{W}(11))-\mathrm{O}(58)$ 90.6(7); O(43)-Re(8)(W(11))-O(55) 82.3(5); O(43)- $\operatorname{Re}(8)(\mathrm{W}(11))-\mathrm{O}(58) \quad 162.8(6) ; \quad \mathrm{O}(55)-\operatorname{Re}(8)(\mathrm{W}(11))-\mathrm{O}(58) \quad 81.7(5) ; \quad \mathrm{O}(32)-$ $\operatorname{Re}(9)(\mathrm{W}(12))-\mathrm{O}(37) \quad 100.3(7) ; \quad \mathrm{O}(32)-\operatorname{Re}(9)(\mathrm{W}(12))-\mathrm{O}(38) \quad 101.6(7) ; \quad \mathrm{O}(32)-\operatorname{Re}(9)(\mathrm{W}(12))-$ $\mathrm{O}(44) \quad 96.9(7) ; \quad \mathrm{O}(32)-\operatorname{Re}(9)(\mathrm{W}(12))-\mathrm{O}(55) \quad 173.4(5) ; \quad \mathrm{O}(32)-\operatorname{Re}(9)(\mathrm{W}(12))-\mathrm{O}(59) \quad 98.5(7) ;$ $\mathrm{O}(37)-\operatorname{Re}(9)(\mathrm{W}(12))-\mathrm{O}(38)$ 157.8(7); O(37)- $\operatorname{Re}(9)(\mathrm{W}(12))-\mathrm{O}(44)$ 88.8(6); O(37)- $\operatorname{Re}(9)(\mathrm{W}(12))-$ $\mathrm{O}(55)$ 73.4(6); O(37)- $\operatorname{Re}(9)(\mathrm{W}(12))-\mathrm{O}(59)$ 88.9(6); O(38)-Re(9)(W(12))-O(44) 85.4(6); O(38)$\operatorname{Re}(9)(\mathrm{W}(12))-\mathrm{O}(55)$ 84.6(6); O(38)- $\operatorname{Re}(9)(\mathrm{W}(12))-\mathrm{O}(59)$ 91.1(6); O(44)-Re(9)(W(12))-O(55) 81.2(6); O(44)-Re(9)(W(12))-O(59) 164.6(7); O(55)-Re(9)(W(12))-O(59) 83.6(6); O(33)$\operatorname{Re}(10)(\mathrm{W}(13))-\mathrm{O}(38)$ 101.9(7); O(33)- $\operatorname{Re}(10)(\mathrm{W}(13))-\mathrm{O}(39)$ 100.0(7); O(33)- $\operatorname{Re}(10)(\mathrm{W}(13))-$ $\mathrm{O}(45)$ 96.1(6); O(33)- $\operatorname{Re}(10)(\mathrm{W}(13))-\mathrm{O}(56)$ 172.5(6); O(33)-Re(10)(W(13))-O(60) 100.7(7); $\mathrm{O}(38)-\operatorname{Re}(10)(\mathrm{W}(13))-\mathrm{O}(39) \quad 157.6(7) ; \quad \mathrm{O}(38)-\operatorname{Re}(10)(\mathrm{W}(13))-\mathrm{O}(45) \quad 84.7(6) ; \quad \mathrm{O}(38)-$ $\operatorname{Re}(10)(\mathrm{W}(13))-\mathrm{O}(56) \quad 84.7(6) ; \mathrm{O}(38)-\operatorname{Re}(10)(\mathrm{W}(13))-\mathrm{O}(60)$ 88.5(6); $\mathrm{O}(39)-\operatorname{Re}(10)(\mathrm{W}(13))-$ $\mathrm{O}(45)$ 88.6(6); O(39)- $\operatorname{Re}(10)(\mathrm{W}(13))-\mathrm{O}(56)$ 73.1(6); O(39)-Re(10)(W(13))-O(60) 91.8(6); $\mathrm{O}(45)-\operatorname{Re}(10)(\mathrm{W}(13))-\mathrm{O}(56) \quad 80.9(5) ; \quad \mathrm{O}(45)-\operatorname{Re}(10)(\mathrm{W}(13))-\mathrm{O}(60) \quad 162.8(6) ; \quad \mathrm{O}(56)-$ $\operatorname{Re}(10)(\mathrm{W}(13))-\mathrm{O}(60)$ 82.7(6); O(34)- $\operatorname{Re}(11)(\mathrm{W}(14))-\mathrm{O}(39)$ 100.0(7); O(34)- $\operatorname{Re}(11)(\mathrm{W}(14))-$ $\mathrm{O}(40)$ 102.2(8); O(34)-Re(11)(W(14))-O(46) 96.5(7); O(34)-Re(11)(W(14))-O(56) 172.5(7); $\mathrm{O}(34)-\operatorname{Re}(11)(\mathrm{W}(14))-\mathrm{O}(61) \quad 99.5(6) ; \quad \mathrm{O}(39)-\operatorname{Re}(11)(\mathrm{W}(14))-\mathrm{O}(40) \quad 157.3(6) ; \quad \mathrm{O}(39)-$ $\operatorname{Re}(11)(\mathrm{W}(14))-\mathrm{O}(46)$ 87.3(7); O(39)- $\operatorname{Re}(11)(\mathrm{W}(14))-\mathrm{O}(56)$ 72.7(5); O(39)- $\operatorname{Re}(11)(\mathrm{W}(14))-$ $\mathrm{O}(61)$ 91.2(7); $\mathrm{O}(40)-\operatorname{Re}(11)(\mathrm{W}(14))-\mathrm{O}(46)$ 85.6(6); O(40)-Re(11)(W(14))-O(56) 85.0(6); $\mathrm{O}(40)-\operatorname{Re}(11)(\mathrm{W}(14))-\mathrm{O}(61) \quad 89.8(6) ; \quad \mathrm{O}(46)-\operatorname{Re}(11)(\mathrm{W}(14))-\mathrm{O}(56) \quad 82.1(5) ; \quad \mathrm{O}(46)-$ $\operatorname{Re}(11)(\mathrm{W}(14))-\mathrm{O}(61)$ 163.9(6); O(56)- $\operatorname{Re}(11)(\mathrm{W}(14))-\mathrm{O}(61)$ 82.2(5); $\mathrm{O}(29)-\operatorname{Re}(12)(\mathrm{W}(15))-$ $\mathrm{O}(35)$ 100.3(7); O(29)-Re(12)(W(15))-O(40) 101.8(7); O(29)-Re(12)(W(15))-O(41) 96.3(7); $\mathrm{O}(29)-\operatorname{Re}(12)(\mathrm{W}(15))-\mathrm{O}(54) \quad 172.4(6) ; \quad \mathrm{O}(29)-\operatorname{Re}(12)(\mathrm{W}(15))-\mathrm{O}(62) \quad 99.3(7) ; \quad \mathrm{O}(35)-$ $\operatorname{Re}(12)(\mathrm{W}(15))-\mathrm{O}(40)$ 157.3(7); O(35)- $\operatorname{Re}(12)(\mathrm{W}(15))-\mathrm{O}(41)$ 88.0(5); O(35)- $\operatorname{Re}(12)(\mathrm{W}(15))-$ $\mathrm{O}(54)$ 72.4(6); $\mathrm{O}(35)-\operatorname{Re}(12)(\mathrm{W}(15))-\mathrm{O}(62)$ 91.2(6); O(40)-Re(12)(W(15))-O(41) 84.6(6); $\mathrm{O}(40)-\operatorname{Re}(12)(\mathrm{W}(15))-\mathrm{O}(54) \quad 85.3(6) ; \quad \mathrm{O}(40)-\operatorname{Re}(12)(\mathrm{W}(15))-\mathrm{O}(62) \quad 90.1(6) ; \quad \mathrm{O}(41)-$ $\operatorname{Re}(12)(\mathrm{W}(15))-\mathrm{O}(54)$ 81.4(6); O(41)- $\operatorname{Re}(12)(\mathrm{W}(15))-\mathrm{O}(62)$ 164.2(8); $\mathrm{O}(54)-\operatorname{Re}(12)(\mathrm{W}(15))-$ $\mathrm{O}(62)$ 83.4(6); O(1)-W(1)-O(4) 102.0(6); O(1)-W(1)-O(5) 101.9(7); O(1)-W(1)-O(8) 102.5(7); $\mathrm{O}(1)-\mathrm{W}(1)-\mathrm{O}(9)$ 102.1(6); O(1)-W(1)-O(25) 171.7(6); O(4)-W(1)-O(5) 88.7(7); O(4)-W(1)-O(8) 87.0(7); O(4)-W(1)-O(9) 155.9(6); O(4)-W(1)-O(25) 72.9(5); O(5)-W(1)-O(8) 155.5(5); O(5)- 
$631 \quad \mathrm{~W}(1)-\mathrm{O}(9) \quad 88.2(7) ; \quad \mathrm{O}(5)-\mathrm{W}(1)-\mathrm{O}(25) \quad 71.8(5) ; \quad \mathrm{O}(8)-\mathrm{W}(1)-\mathrm{O}(9) \quad 86.1(7) ; \quad \mathrm{O}(8)-\mathrm{W}(1)-\mathrm{O}(25)$ 632 83.9(5); O(9)-W(1)-O(25) 83.5(5); O(2)-W(2)-O(5) 102.4(6); O(2)-W(2)-O(6) 101.5(7); O(2)633 W(2)-O(10) 103.6(8); O(2)-W(2)-O(11) 101.8(7); O(2)-W(2)-O(25) 171.7(6); O(5)-W(2)-O(6) 634 87.7(6); O(5)-W(2)-O(10) 87.2(6); O(5)-W(2)-O(11) 155.8(7); O(5)-W(2)-O(25) 72.9(6); O(6)635 W(2)-O(10) 154.9(7); O(6)-W(2)-O(11) 87.1(6); O(6)-W(2)-O(25) 71.8(6); O(10)-W(2)-O(11) 87.6(6); O(10)-W(2)-O(25) 83.3(7); O(11)-W(2)-O(25) 83.0(6); O(3)-W(3)-O(4) 103.2(6); $\mathrm{O}(3)-\mathrm{W}(3)-\mathrm{O}(6)$ 101.7(7); O(3)-W(3)-O(7) 102.2(7); O(3)-W(3)-O(12) 101.3(6); O(3)-W(3)$\mathrm{O}(25)$ 172.4(7); O(4)-W(3)-O(6) 89.2(7); O(4)-W(3)-O(7) 87.4(6); O(4)-W(3)-O(12) 155.4(6); $\mathrm{O}(4)-\mathrm{W}(3)-\mathrm{O}(25)$ 73.4(5); O(6)-W(3)-O(7) 156.0(6); O(6)-W(3)-O(12) 88.0(7); O(6)-W(3)$\mathrm{O}(25)$ 71.7(6); O(7)-W(3)-O(12) 85.4(6); O(7)-W(3)-O(25) 84.5(6); O(12)-W(3)-O(25) 82.6(5); $\mathrm{O}(42)-\mathrm{W}(16)-\mathrm{O}(43)$ 87.8(7); O(42)-W(16)-O(47) 102.4(7); O(42)-W(16)-O(50) 87.8(6); O(42)$\mathrm{W}(16)-\mathrm{O}(51)$ 155.2(6); O(42)-W(16)-O(53) 82.9(5); O(43)-W(16)-O(47) 103.3(7); O(43)$\mathrm{W}(16)-\mathrm{O}(50) \quad 157.1(6) ; \quad \mathrm{O}(43)-\mathrm{W}(16)-\mathrm{O}(51) \quad 89.2(7) ; \quad \mathrm{O}(43)-\mathrm{W}(16)-\mathrm{O}(53) \quad 84.0(6) ; \quad \mathrm{O}(47)-$ $\mathrm{W}(16)-\mathrm{O}(50)$ 99.6(7); O(47)- W(16)-O(51) 102.2(7); O(47)-W(16)-O(53) 171.0(5); O(50)$\mathrm{W}(16)-\mathrm{O}(51)$ 85.4(7); O(50)-W(16)-O(53) 73.1(6); O(51)-W(16)-O(53) 72.3(5); O(44)-W(17)$\mathrm{O}(45)$ 86.8(6); O(44)-W(17)-O(48) 101.3(7); O(44)-W(17)-O(51) 91.4(6); O(44)-W(17)-O(52) 157.7(6); O(44)-W(17)-O(53) 85.4(6); O(45)-W(17)-O(48) 102.4(6); O(45)-W(17)-O(51) 157.3(7); O(45)-W(17)-O(52) 87.9(7); O(45)-W(17)-O(53) 82.9(6); O(48)-W(17)-O(51) 100.1(6); O(48)-W(17)-O(52) 100.9(7); O(48)-W(17)-O(53) 171.5(7); O(51)-W(17)-O(52) 85.3(7); O(51)-W(17)-O(53) 74.4(5); O(52)-W(17)-O(53) 72.4(6); O(41)-W(18)-O(46) 87.6(6); $\mathrm{O}(41)-\mathrm{W}(18)-\mathrm{O}(49) \quad 101.8(8) ; \quad \mathrm{O}(41)-\mathrm{W}(18)-\mathrm{O}(50)$ 89.3(6); O(41)-W(18)-O(52) 157.7(7); $\mathrm{O}(41)-\mathrm{W}(18)-\mathrm{O}(53) \quad 84.8(6) ; \quad \mathrm{O}(46)-\mathrm{W}(18)-\mathrm{O}(49) \quad 102.1(7) ; \quad \mathrm{O}(46)-\mathrm{W}(18)-\mathrm{O}(50)$ 158.9(7); $\mathrm{O}(46)-\mathrm{W}(18)-\mathrm{O}(52)$ 89.4(7); O(46)-W(18)-O(53) 85.3(6); O(49)-W(18)-O(50) 98.9(7); O(49)$\mathrm{W}(18)-\mathrm{O}(52)$ 100.5(7); O(49)-W(18)-O(53) 170.2(6); O(50)-W(18)-O(52) 85.7(6); O(50)$\mathrm{W}(18)-\mathrm{O}(53)$ 73.6(6); O(52)-W(18)-O(53) 72.9(6); O(25)-P(1)-O(26) 107.4(8); O(25)-P(1)$\mathrm{O}(27)$ 106.8(8); $\mathrm{O}(25)-\mathrm{P}(1)-\mathrm{O}(28)$ 106.4(7); O(26)-P(1)-O(27) 112.6(8); O(26)-P(1)-O(28) 112.2(8); O(27)-P(1)-O(28) 111.0(8); O(53)-P(2)-O(54) 107.0(8); O(53)-P(2)-O(55) 106.4(7); $\mathrm{O}(53)-\mathrm{P}(2)-\mathrm{O}(56)$ 106.3(6); O(54)-P(2)-O(55) 112.9(7); O(54)-P(2)-O(56) 113.0(8); O(55)$\mathrm{P}(2)-\mathrm{O}(56)$ 110.8(8); W(1)-O(4)-W(3) 123.7(7); W(1)-O(5)-W(2) 124.9(7); W(2)-O(6)-W(3) 125.5(7); $\operatorname{Re}(6)(\mathrm{W}(9))-\mathrm{O}(7)-\mathrm{W}(3)$ 150.1(8); $\operatorname{Re}(1)(\mathrm{W}(4))-\mathrm{O}(8)-\mathrm{W}(1)$ 151.3(9); $\operatorname{Re}(2)(\mathrm{W}(5))-$ $\mathrm{O}(9)-\mathrm{W}(1)$ 150.7(10); $\operatorname{Re}(3)(\mathrm{W}(6))-\mathrm{O}(10)-\mathrm{W}(2)$ 150.0(9); $\operatorname{Re}(4)(\mathrm{W}(7))-\mathrm{O}(11)-\mathrm{W}(2)$ 150.4(7); $\operatorname{Re}(5)(\mathrm{W}(8))-\mathrm{O}(12)-\mathrm{W}(3) \quad 153.0(8) ; \operatorname{Re}(1)(\mathrm{W}(4))-\mathrm{O}(19)-\operatorname{Re}(6)(\mathrm{W}(9))$ 124.0(9); $\operatorname{Re}(1)(\mathrm{W}(4))-$ $\mathrm{O}(20)-\operatorname{Re}(2)(\mathrm{W}(5))$ 152.9(8); $\operatorname{Re}(2)(\mathrm{W}(5))-\mathrm{O}(21)-\operatorname{Re}(3)(\mathrm{W}(6))$ 122.4(8); $\operatorname{Re}(3)(\mathrm{W}(6))-\mathrm{O}(22)-$ $\operatorname{Re}(4)(\mathrm{W}(7)) \quad 151.7(9) ; \quad \operatorname{Re}(4)(\mathrm{W}(7))-\mathrm{O}(23)-\operatorname{Re}(5)(\mathrm{W}(8)) \quad 122.6(7) ; \quad \operatorname{Re}(5)(\mathrm{W}(8))-\mathrm{O}(24)-$ $\mathrm{Re}(6)(\mathrm{W}(9))$ 151.7(9); W(1)-O(25)-W(2) 90.3(5); W(1)-O(25)-W(3) 89.9(4); W(1)-O(25)-P(1) 123.8(6); W(2)-O(25)-W(3) 90.9(4); W(2)-O(25)-P(1) 126.4(8); W(3)-O(25)-P(1) 124.7(8); $\operatorname{Re}(1)(\mathrm{W}(4))-\mathrm{O}(26)-\operatorname{Re}(6)(\mathrm{W}(9)) \quad 90.1(6) ; \operatorname{Re}(1)(\mathrm{W}(4))-\mathrm{O}(26)-\mathrm{P}(1) \quad 128.6(8) ; \operatorname{Re}(6)(\mathrm{W}(9))-$ $\mathrm{O}(26)-\mathrm{P}(1) \quad 128.6(7) ; \quad \operatorname{Re}(2)(\mathrm{W}(5))-\mathrm{O}(27)-\operatorname{Re}(3)(\mathrm{W}(6)) \quad 90.3(6) ; \quad \operatorname{Re}(2)(\mathrm{W}(5))-\mathrm{O}(27)-\mathrm{P}(1)$ 127.8(8); $\quad \operatorname{Re}(3)(\mathrm{W}(6))-\mathrm{O}(27)-\mathrm{P}(1) \quad 128.3(8) ; \quad \operatorname{Re}(4)(\mathrm{W}(7))-\mathrm{O}(28)-\operatorname{Re}(5)(\mathrm{W}(8)) \quad 90.6(4) ;$ $\operatorname{Re}(4)(\mathrm{W}(7))-\mathrm{O}(28)-\mathrm{P}(1)$ 128.2(9); $\operatorname{Re}(5)(\mathrm{W}(8))-\mathrm{O}(28)-\mathrm{P}(1)$ 127.2(8); $\operatorname{Re}(7)(\mathrm{W}(10))-\mathrm{O}(35)-$ $\operatorname{Re}(12)(\mathrm{W}(15))$ 123.9(9); $\operatorname{Re}(7)(\mathrm{W}(10))-\mathrm{O}(36)-\operatorname{Re}(8)(\mathrm{W}(11))$ 151.8(6); $\operatorname{Re}(8)(\mathrm{W}(11))-\mathrm{O}(37)-$ $\operatorname{Re}(9)(\mathrm{W}(12))$ 122.7(8); $\operatorname{Re}(9)(\mathrm{W}(12))-\mathrm{O}(38)-\operatorname{Re}(10)(\mathrm{W}(13))$ 152.9(9); $\operatorname{Re}(10)(\mathrm{W}(13))-\mathrm{O}(39)-$ $\operatorname{Re}(11)(\mathrm{W}(14)) \quad 123.6(7) ; \quad \operatorname{Re}(11)(\mathrm{W}(14))-\mathrm{O}(40)-\operatorname{Re}(12)(\mathrm{W}(15)) \quad 153.3(8) ; \quad \operatorname{Re}(12)(\mathrm{W}(15))-$ $\mathrm{O}(41)-\mathrm{W}(18) \quad 150.1(9) ; \operatorname{Re}(7)(\mathrm{W}(10))-\mathrm{O}(42)-\mathrm{W}(16) \quad 149.4(10) ; \quad \operatorname{Re}(8)(\mathrm{W}(11))-\mathrm{O}(43)-\mathrm{W}(16)$ 150.4(10); $\operatorname{Re}(9)(\mathrm{W}(12))-\mathrm{O}(44)-\mathrm{W}(17) \quad 150.1(8) ; \quad \operatorname{Re}(10)(\mathrm{W}(13))-\mathrm{O}(45)-\mathrm{W}(17)$ 151.1(7); $\operatorname{Re}(11)(\mathrm{W}(14))-\mathrm{O}(46)-\mathrm{W}(18)$ 148.4(7); W(16)-O(50)-W(18) 122.5(8); W(16)-O(51)-W(17) 123.3(7); W(17)-O(52)-W(18) 123.2(7); W(16)-O(53)-W(17) 90.0(4); W(16)-O(53)-W(18) 90.8(5); W(16)-O(53)-P(2) 124.1(6); W(17)-O(53)-W(18) 91.5(4); W(17)-O(53)-P(2) 125.3(9); $\mathrm{W}(18)-\mathrm{O}(53)-\mathrm{P}(2) \quad 124.9(8) ; \quad \operatorname{Re}(7)(\mathrm{W}(10))-\mathrm{O}(54)-\operatorname{Re}(12)(\mathrm{W}(15)) \quad 90.6(6) ; \quad \operatorname{Re}(7)(\mathrm{W}(10))-$ $\mathrm{O}(54)-\mathrm{P}(2)$ 129.0(7); $\operatorname{Re}(12)(\mathrm{W}(15))-\mathrm{O}(54)-\mathrm{P}(2)$ 127.8(7); $\operatorname{Re}(8)(\mathrm{W}(11))-\mathrm{O}(55)-\operatorname{Re}(9)(\mathrm{W}(12))$ 90.4(5); $\quad \operatorname{Re}(8)(\mathrm{W}(11))-\mathrm{O}(55)-\mathrm{P}(2) \quad 127.2(8) ; \quad \operatorname{Re}(9)(\mathrm{W}(12))-\mathrm{O}(55)-\mathrm{P}(2) \quad$ 130.2(7); $\operatorname{Re}(10)(\mathrm{W}(13))-\mathrm{O}(56)-\operatorname{Re}(11)(\mathrm{W}(14)) \quad 90.3(4) ; \quad \operatorname{Re}(10)(\mathrm{W}(13))-\mathrm{O}(56)-\mathrm{P}(2) \quad 128.6(8) ;$ $\operatorname{Re}(11)(\mathrm{W}(14))-\mathrm{O}(56)-\mathrm{P}(2) \quad 127.8(9) ; \quad \operatorname{Re}(1)(\mathrm{W}(4))-\mathrm{O}(57)-\operatorname{Re}(7)(\mathrm{W}(10)) \quad 160.2(10) ;$ 
$684 \quad \operatorname{Re}(2)(\mathrm{W}(5))-\mathrm{O}(58)-\operatorname{Re}(8)(\mathrm{W}(11)) \quad 165.3(11) ; \quad \operatorname{Re}(3)(\mathrm{W}(6))-\mathrm{O}(59)-\operatorname{Re}(9)(\mathrm{W}(12)) \quad 162.0(8) ;$ $685 \quad \operatorname{Re}(4)(\mathrm{W}(7))-\mathrm{O}(60)-\operatorname{Re}(10)(\mathrm{W}(13)) \quad 163.4(8) ; \quad \operatorname{Re}(5)(\mathrm{W}(8))-\mathrm{O}(61)-\operatorname{Re}(11)(\mathrm{W}(14)) \quad 163.7(9) ;$ $686 \operatorname{Re}(6)(\mathrm{W}(9))-\mathrm{O}(62)-\operatorname{Re}(12)(\mathrm{W}(15)) 162.0(9)$.

687

688

689 